\title{
Deposits from the Glacial Age at Lake Baikal
}

\author{
N.I. Akulov and M.N. Rubtsova \\ Institute of the Earth's Crust, Siberian Branch of the RAS \\ Russia
}

\section{Introduction}

Lake Baikal is one of the unique sites on the globe. Its huge freshwater reserves were accumulated over the course of several geological epochs, with Pleistocene glaciations having had an important role in this respect. Clean melt waters from the numerous glaciers that were descending down the surrounding mountain ranges serves as the main supplier of freshwater. The Quaternary glaciation in East Siberia was stronger when compared with Europe, but because of the insufficient amount of moisture in air masses over Central Asia, a permanent snow cover persisted only on the mountain ranges and on their arms. This factor is responsible for a significant depth of freezing of sedimentary rocks ("eternal" frost, or permafrost), and for the occurrence of a smaller (in area and thickness) glacial shield advancing from the Arctic Ocean. Recent years saw the emergence of intensive studies into palaeoclimatic changes, based on analyzing core material from bottom sediments in Baikal. The history of the "Drilling on Baikal" or "Baikal-Drilling" program is widely known from publications of such outstanding scientists as M.I. Kuzmin, G.K. Khursevich, A.A. Prokopenko, S.A. Fedenya, and E.B. Karabanov (Kuzmin et al., 2009); S.M. Colman, J.A. Peck, E.B. Karabanov S. J. Carter, J. P. Bradbury, J.W. King and D.F. Williams (Colman et al., 1995); T.G. Moore, K.D. Klitgord, A.Ya. Golmstok, and E. Weber (Moore et al., 1997), and others. The program has opened up a new era in the palaeoclimatic investigations into the Baikal hollow. The point is that as early as 1989 D.F. Williams, professor of South Carolina University, suggested to their Russian colleagues that a cooperative project be started aimed at studying global changes in the natural environment and climate of Central Asia based on deep-water drilling on Baikal. In 1992, Japanese scientists headed by Professor Sh. Horie joined the "Baikal-Drilling" project. As part of the drilling operations, several continuous palaeoclimatic records covering a time span of several million years were obtained. The question as to how these palaeoclimatic records are correlated with intra-continental deposits is a currently challenging palaeoclimatic problems of Central Asia which will remain one of the "hottest" areas for many years to come.

\section{Background and formulation of the problems}

Prince P.A. Kropotkin was the first to investigate the glacial deposits of the Baikal mountainous region surrounding Lake Baikal. Drawing on the characteristic glacial striation on rocks and on the numerous erratic boulders of granitoid composition, P.A. Kropotkin (1876) found for the first time that the entire northern part of Pribaikalie and the Patoma 
Upland underwent glaciation at some time in the past. He suggested that the glaciation was two-fold. P.A. Kropotkin's conclusions were sharply objected by I.D. Chersky (1877) and A.I. Voyeikov (1952), who argued that formation of blanket glaciers is simply impossible in a dry climate. Later, the ancient glacial forms in the Baikal mountainous region were studied by Academician V.A. Obruchev (1931), who found that the permafrost in this region is more than a hundred meters in depth and that a relatively local occurrence of a significant amount of products of glacial activity points to the fact that the glaciation was discontinuous (patchy) rather than continuous. Subsequent researchers concerned with Quaternary deposits at Lake Baikal (Yatsenko, 1950; Gurulev, 1959; Voskresensky, 1959; Lamakin, 1961; 1963; Olyunin, 1969) suggested that this region experienced two glaciations that manifested themselves during the Mid- and Late Pleistocene. To substantiate the Mid-Late Pleistocene Interglacial in the southwestern Pribaikalie, S.S. Voskresensky (1959) used deposits from the 35- and 22-meter terraces of the Angara characterized by pollen from heat-loving vegetation. The eminent glaciologist M.G. Grosvald (1965), who studied in detail the deposits from the glacial age on the western slopes of Eastern Sayan, reconstructed the pattern of thricerepeated glaciation. Around the same time E.I. Ravsky and collaborators (Ravsky et al., (Rayevsky et al., 1964) and S.M. Tseitlin (1964), based on analyzing the terrace deposits along the valley of the Angara and Lower-Tunguska rivers, suggested that there occurred a fourfold glaciation. Somewhat later, this same conclusion was arrived at by O.M. Adamenko, A.A. Kul'chitsky and R.S. Adamenko (Adamenko et al., 1974) as well as by N.A. Logachev and collaborators (Logachev et al., 1974) and S. Back with R.M. Strecker (Back, Strecker, 1998). After many years of investigations into the morphology of the glacier relief in the mountains of the northern part of the Baikal mountainous region, an outstanding geomorphologists A.G. Zolotarev (1961) identified traces of the six-fold movement of the valley glaciers. However, because of lack of exhaustive geologo-palaeogeomorphological factual evidence, he was unable to discriminate between traces corresponding to independent glaciations and traces corresponding to stages or oscillatory movements. On the other hand, among the geomorphologists studying the Baikal mountainous region there appeared adherent to the concept of thrice-repeated glaciation. According to data reported by N.V. Dumitrashko (1952), there occurs no complete thawing away of the glaciers throughout the Pleistocene. She considers the entire glacial age to be a common glaciation and attributes the terminal moraines to the phase changes in the glaciers. Among the four phases identified, she assigns the oldest phase to the Pliocene, the second (maximal) phase to the Early Pleistocene, and the last two phases to the end of the glacial age (Late Pleistocene). The possible existence of a single glaciation in the past was also supported by N.P. Ladokhin (1959) and V.V. Zamoruyev $(1971,1978)$. According to the conclusion drawn by V.V. Zamoruyev (1971), the age of the morainic deposits that were stripped at the foot of the southern part of Khamar-Daban does not exceed the length of the Mid-Pleistocene, but they became of widespread occurrence at the end of the Late Pleistocene (Sartanian time). Over the course of many years, N.A. Logachev (Logachev et al., 1964; 1974), A.A. Kul'chitsky (1973; 1985; 1993), S.S. Osadchy (1982), D.B. Bazarov (1986), A.B. Imetkhenov (1987), V.D. Mats (Mats et al., 1982; 2001), and other workers were concerned with investigations into the geology of Quaternary deposits and, accordingly, into glacial formations at Lake Baikal. Their geological research was instrumental in substantially complementing and systematizing the data on Quaternary deposits of Lake Baikal. The results obtained through the implementation of the international "Baikal-Drilling" project aroused considerable interest in reconstructing the climatic changes at Lake Baikal during 
the Pleistocene (Team ..., 1998). Deep-water drilling operations on Baikal provided continuous palaeoclimatic records for Central Asia for the last $10 \mathrm{mln}$ years. It was found that at the period of global glaciations there disappeared diatom algae, and the lake was drainless. Also, its water level was 30-50 m below the contemporary elevation. Among the recent investigations into the Pleistocene-Holocene deposits of the Baikal mountainous country, the research done by S.K. Krivonogov (2010) deserves mention. Drawing on geomorphological data, he found that the Tyiskaya phase of technogenesis that occurred in the Mid-Late Pleistocene brought about a significant differentiation of the relief. The emergence of high mountains caused the cold climatic belt to expand, so that at the time of the last global cooling during the Late Pleistocene the mountains surrounding the hollows became a region of intense glaciation which determined, to a significant extent, the pattern of sedimentation. According to his data, the maximum of Pleistocene glaciation in the mountains of the inner parts of Eurasia corresponds to the first half of the Late Pleistocene (100-70 ths years ago), which differs drastically from the glaciation in the mountains of oceanic areas, with their maximum occurring about 20 ths years ago. The publications cited above contributed to a general understanding of the complicated history of Quaternary glaciation evolution in East Siberia. Almost all the references cited above point out an involved glaciation degradation process and identified a number of stadial terminal moraines. On the other hand, there is no consensus among researchers even regarding the key issues relating to ancient glaciation. It is well known that global changes in atmospheric circulation, humidification, hydrographic network and in the regime of river runoff, continental sedimentogenesis and soil-formation processes as well as migration of flora, fauna and ancient man were associated with the evolution of glaciation. The geological activity of glaciers and associated processes was responsible for the peculiar kind of landscapes of regions occupied by ancient glaciers. Besides, they played an important role for the preservation or destruction of Pleistocene placers of gold and other metals (Obruchev, 1931; Kazakevich and Vashko, 1965). Therefore, the resolution of the ancient glaciation problems has not only a scientific-technological but also important practical significance. The primary objectives of this study are: 1) to identify the main types of glacial deposits and study their matter composition, and 2) to carry out a correlation of the products of activity of Quaternary glaciation in the continental part of the lake, with an attempt to correlate them with the time frames of the glaciations as identified using deepwater drilling cores of bottom sediments from lake Baikal.

\section{Materials and methods of investigation}

This paper draws on results from the expedition-based research done in the arms of the Baikalsky, Akitkansky, Barguzinsky and Khamar-Daban Ranges surrounding Lake Baikal (Fig. 1). Furthermore, this investigation used the results from a lithological study of deepwater drilling cores BDP-97 and BDP-99, under the Baikal Drilling Project (Team ..., 1998). Thus, to achieve the objectives of this study, use was made of the field and laboratory investigation techniques for Quaternary deposits. Field investigations involved a local survey of glacial, fluvioglacial and morainic landforms. A study was made of the lithologofacial composition of Pleistocene deposits and their relationship with the deposits of conjugate terraces on the shores of Lake Baikal. The lithological and palynological investigations were carried out in the Laboratory of Stratigraphy and Lithogenesis at the Institute of the Earth's Crust SB RAS (Irkutsk). A total of 356 samples were subjected to 
granulometric and mineralogical analyses, and an X-ray diffraction analysis was made of clay fraction. The particle-size composition of subaerial sediments was determined through sieving (fractions of $>1.0 ; 1.0-0.5 ; 0.5-0.25 ; 0.25-0.1$, and $0.1-0.05 \mathrm{~mm}$ ) and elutriation (fractions of 0.05-0.001 and $<0.001 \mathrm{~mm}$ ) after $20 \mathrm{~min}$ and $24 \mathrm{~h}$, respectively (Strakhov, 1957). All mineral grains 0.05 to $0.25 \mathrm{~mm}$ in size were separated with bromoform into light and heavy fractions to be thoroughly studied in immersion preparations. A mineral-based classification of sand-silty deposits was performed according to a systematization proposed by Shutov (1972), and a classification of terrigenous material and determination of its degree of roundness were made following Rukhin (1969). The analyses were made by S.P. Sumkina (particle-size composition), I.A. Kalashnikova \& E.G. Polyakova (mineral composition), O.N. Shestakova \& N.V. Kulagina (palynological composition), and by T.S. Fileva \& M.N. Rubtsova (clay fraction).

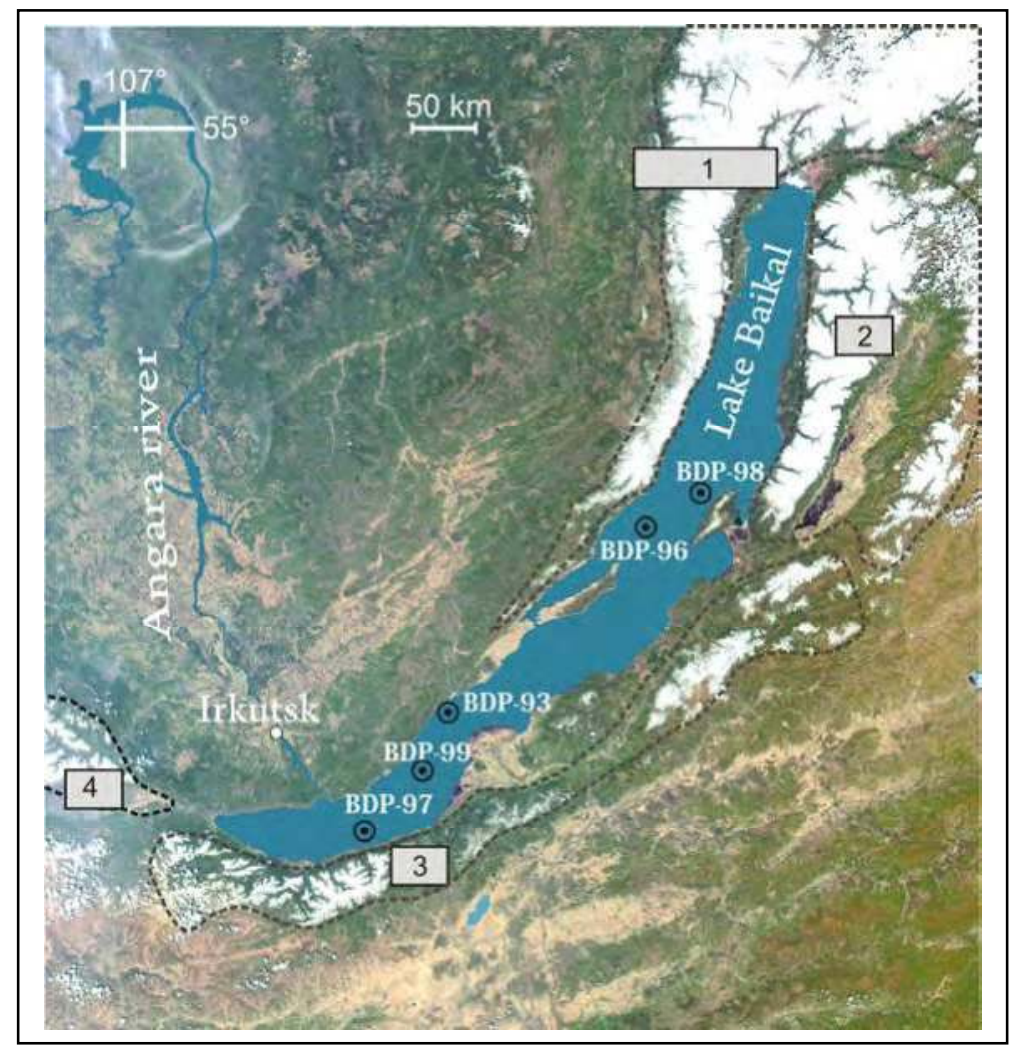

Fig. 1. Satellite image of the study region with the dashes showing the main Quaternary glaciations units at lake Baikal: 1 - Northwestern (Primorsky, Baikalsky, Akitkansky and other mountain ranges); 2 - Eastern (Barguzinsky and Ikatsky ranges); 3 - Southeastern (Khamar-Daban and Ulan-Burgasy mountain ranges); 4 - Southwestern (mountain structures of Eastern Sayan). BDP - deep-water boreholes under the "Baikal Drilling Project". The spring 2010 image of Lake Baikal is used as the basis (Ministry of Natural Resources of Russia, Baikal Information Computer Center, www.geol.irk.ru). Snow-covered mountain summits which were experiencing glaciations appear white. 


\section{Results}

Within the Baikal mountainous country we identify four u7nits of Pleistocene glaciation: Northwestern (the Primorsky, Baikalsky, Akitkansky, Delyun-Uransky and Synnyrsky Ranges), Eastern (the Barguzinsky and Ikatsky Ranges), Southeastern (the Khamar-Daban and Ulan-Burgas Ranges), and Southwestern (the mountain structures of Eastern Sayan) (Fig. 1). The northwestern unit is the most immense region of glaciation. It was an extensive province feeding the numerous mountain-valley glaciers that descended at different times to the Baikal hollow, and to the Prebaikalian foredeep. A geological mapping of the glacial deposits that was carried out in one of the areas of this unit was instrumental in reconstructing the paths of the individual glaciers. They are quite well traceable from ridges and hills of aqueous-glacial layers (oses and kames) and the numerous sediments of the lake-bog type and end with banks of morainic deposits (Figs. 2 and 3).

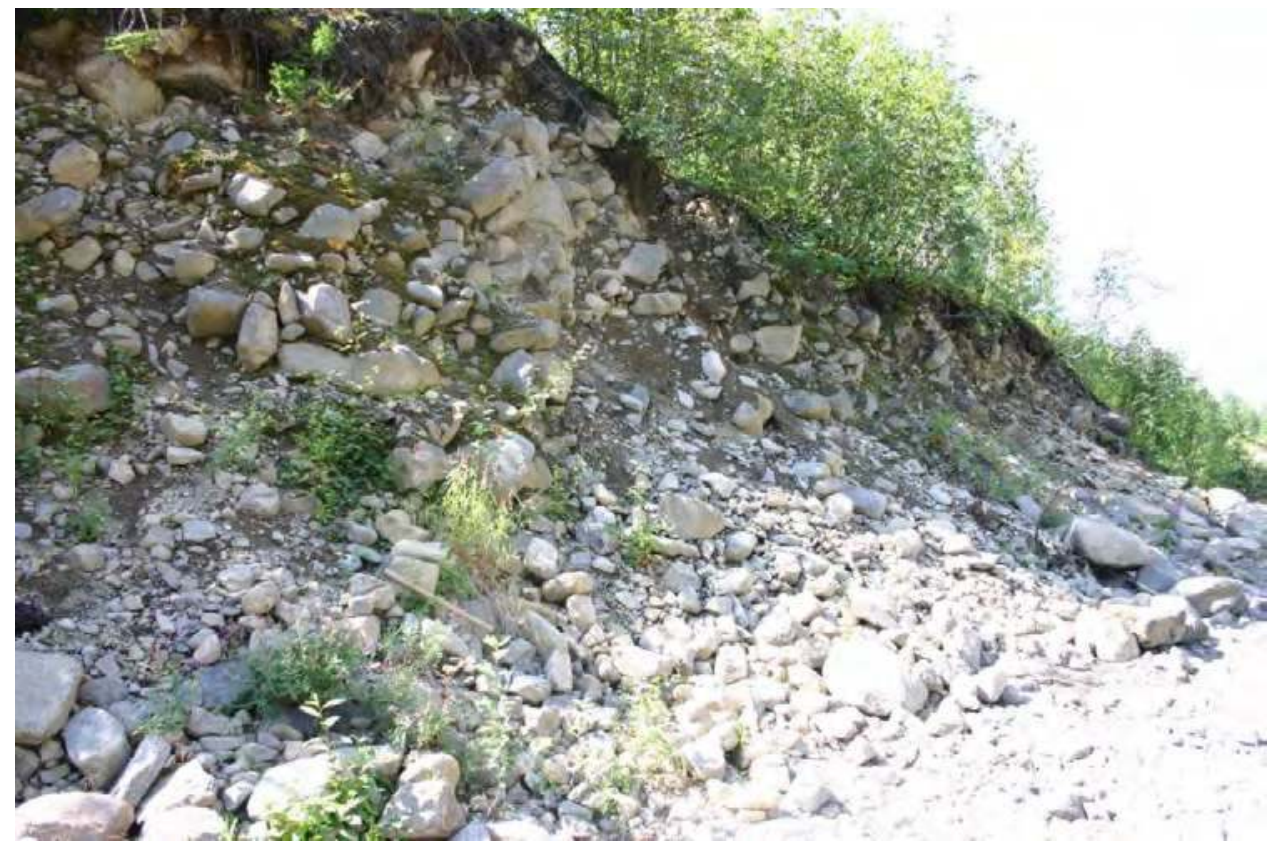

Fig. 2. Sand-boulder-block morainic deposits of the Del'bichinda rock unit (mouth of the Del'bichinda River; Northwestern glaciations unit, see Fig. 1.

\subsection{Morainic deposits}

Morainic deposits occur mainly in the foothill area. Only occasional moraines penetrated deep into the Cisbaikalian basin, to a distance of up to $20 \mathrm{~km}$ (the Minya-Okunaika interfluve). Most likely, they were brought by thick glaciers from the Baikalsky and Akitkan Ranges. We have studied the sections of morainic deposits in arms of the Baikalsky Range at an absolute altitude of $767 \mathrm{~m}$ (N: 5544' 05,1"; E: 108 $44^{\prime}$ 22,6"). Here, across the wide valley of the Kunerma River, near the mouth of its right tributary, the Del'bichinda River, morainic deposits (morainic bar) are outcropping, with their visible thickness being $21 \mathrm{~m}$. The depth 
of the valley increases from $625 \mathrm{~m}$ in the Davan mountain pass to $950 \mathrm{~m}$ at the place where the Kunerma River leaves the mountains; the slope dip of the valley increases correspondingly from $20^{\circ}$ to $30-35^{\circ}$, and the width of the area between its brows, on the contrary, decreases from 7 to $3.5-4 \mathrm{~km}$. The valley bottom narrows from 1.7 to $1-0.5 \mathrm{~km}$ when approaching the ridge margin and drastically widens only at the river exit to the Central Siberian upland. In the Kunerma valley, the arms of the Baikalsky Range are virtually at the same absolute altitude, $1400-1700 \mathrm{~m}$. The absolute altitudes of the valley bottom decrease from $980 \mathrm{~m}$ in the Davan mountain pass to $519 \mathrm{~m}$ at the river exit from the mountains. The downstream slope of the valley bottom averages $9 \mathrm{~m} / \mathrm{km}$. Near the mouth of the Del'bichinda River (in the area of the village of Granitnyi), the reconstructed valley along which a glacier moved has a bottom slope of $20 \mathrm{~m} / \mathrm{km}$ and a slope dip of $20^{\circ}$. The slopes are complicated by tectonic benches, especially well expressed over a $4 \mathrm{~km}$ stretch of the Del'bichinda River. Owing to these benches, the slopes locally look as a staircase. Similar benches exist on mountain slopes along the Kunerma valley as well as in areas north of the Medvezhii Brook and between the latter and the Dikii Brook. The benches are composed mainly of fractured bedrocks separated into blocks and plates. The loose sedimentary cover of the slopes is thin and broken. Below the slope piedmonts, it occurs as separate relics mainly in relief sinks, overlying Proterozoic granodiorites and orthogneisses. The relics are unstratified sand-boulder-block (Fig. 2) and block-boulder-sand (Fig. 3) deposits with debris and gruss, which form a thick uniform rock unit called by us "Del'bichinda" Akulov et al., 2008). Gray silty inequigranular sand is the main filling material occurring in the form of a polymict glacier milk. All sediments are intensely milled but absolutely unsorted, because

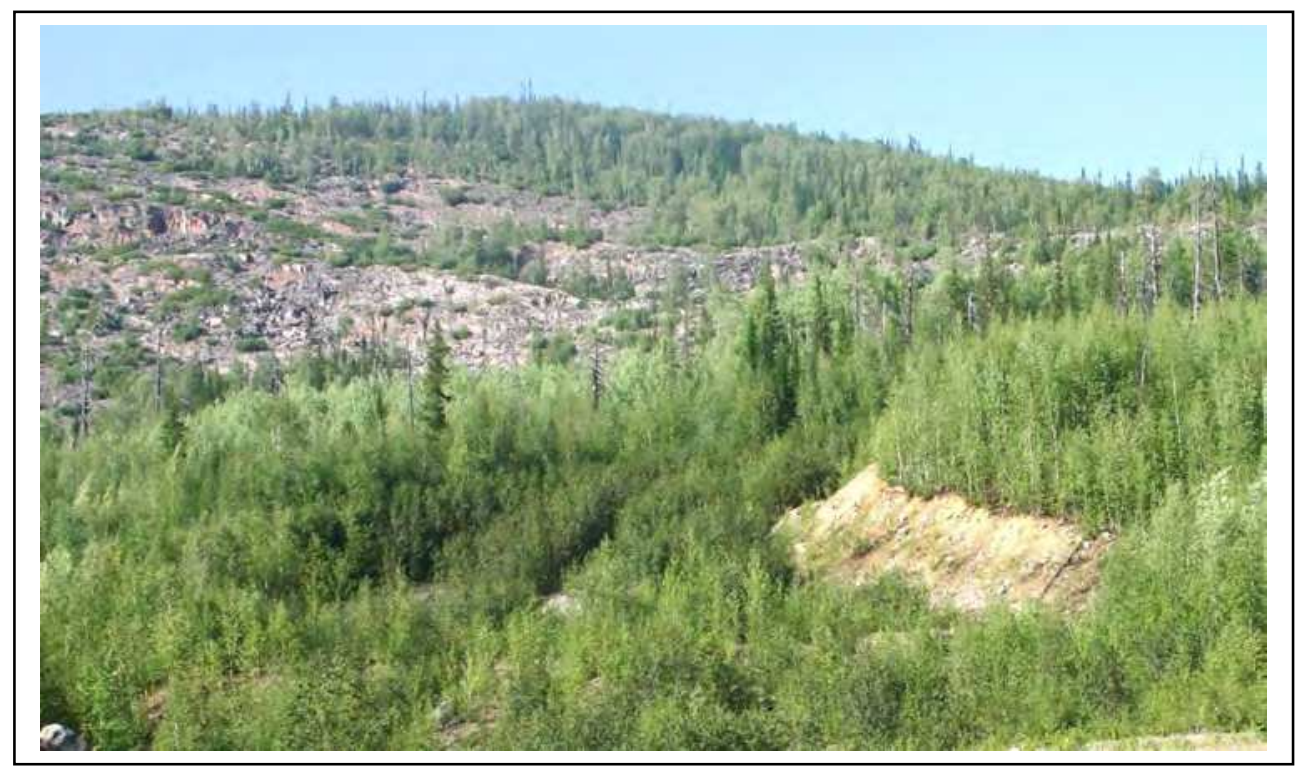

Fig. 3. Boulder-pebble-sand morainic deposits on the northwestern slope of the Baikalsky Range. Block-boulder-sand morainic deposits (Granitnyi Village region; Northwestern glaciations unit). 
the glacial meltwaters did not participate in their lithologic formation. Rock fragments that occur in these deposits are of the first and second roundness grades. In places, elongate boulders and pebbles among the morainic deposits are oriented so that their long axes are directed along the glacier movement, i.e., along the strike of the ancient valleys. We

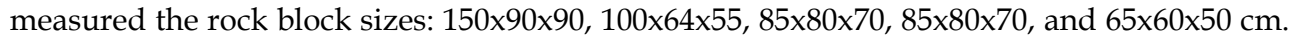
The blocks, boulders, and pebbles have the same petrographic composition: granitoids, quartzites, felsitic and quartz porphyry, amphibolites, etc. We also discovered glacier scores on the surface of some boulders and large pebbles from the base of the studied morainic deposits (Fig. 4). Erratic blocks are chaotically scattered across the territory o glaciation, and only the upper part of the largest of them outcrops to the day surface (Fig. 5). Counting of the rows of morainic bars showed that there were no less than seven mountain glaciers that slipped down to the Cisbaikalian basin from the side of the Akitkan Ridge, whereas in the Baikal Ridge area we have revealed only five rows of terminal moraines. Probably, part of the bars is the result of oscillations of the same glacier. In plan, the terminal moraines are segments, 3 to $12 \mathrm{~km}$ long, arranged in a fan. As seen in the schematic geologic section, these segment-like morainic bars support each other. In the Minya-Okunaika interfluve, terminal morainic bars reach $1.5 \mathrm{~km}$ in length, $600 \mathrm{~m}$ in width, and $30 \mathrm{~m}$ in height. They are composed of sand-gravel deposits and pebbles with some boulders. The sand-gravel deposits are unstratified; only locally there are inequigranular sands with horizontal and oblique layering. Large obliquely layered rock series usually pinch out over a distance of 12 to $25 \mathrm{~m}$, giving way to laterally layered gravel-pebble deposits. Our laboratory studies of the Del'bichinda unit deposits showed that the granulometric composition of sand-silty fraction gradually changes from base to roof of the moraine (Fig. 6). The lower part of the unit is

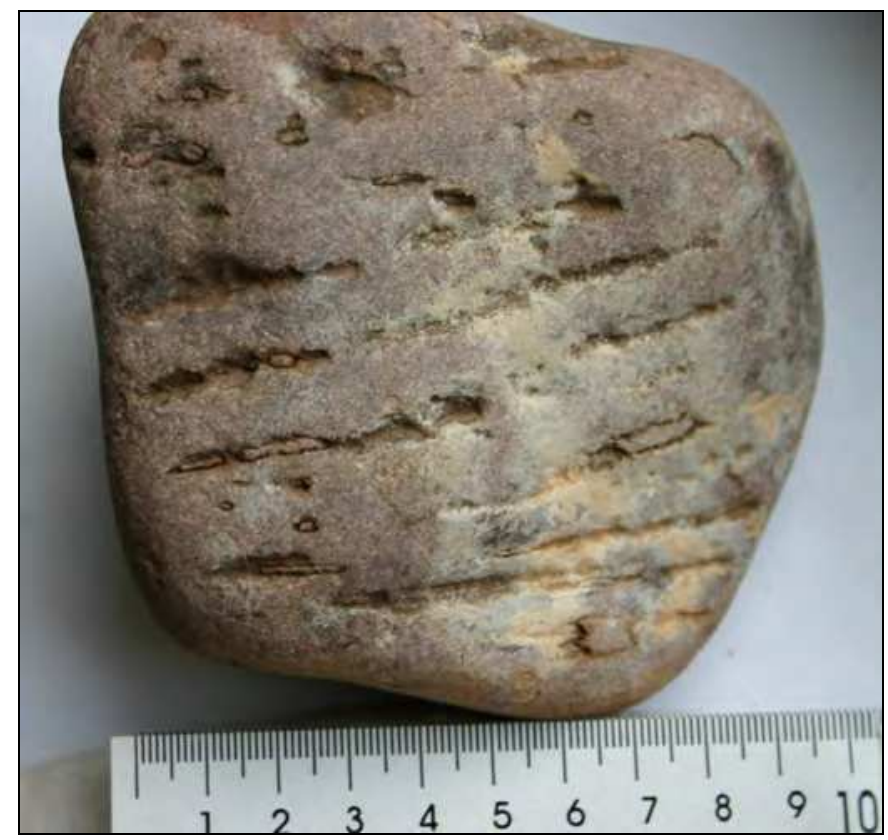

Fig. 4. Glacial scores on boulder (Del'bichinda rock unit; Northwestern glaciations unit). 


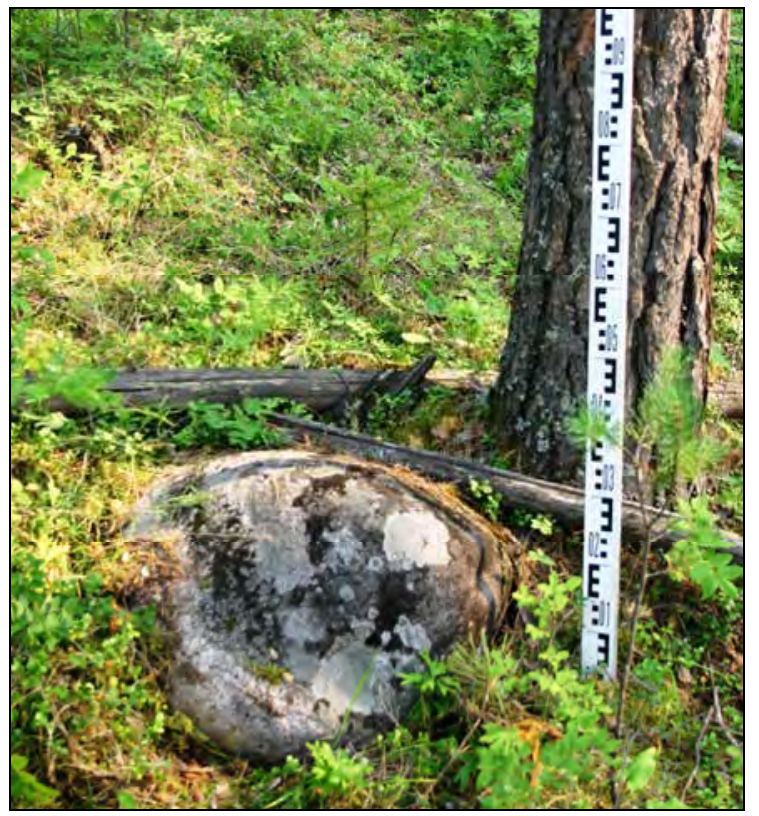

Fig. 5. Erratic blocks and boulders were scattered by the glaciers across the taiga plains of the western Pribaikalie, and only the upper part of the largest blocks outcrops to the day surface. Northwestern glaciation unit.

dominated by inequigranular sands containing 22-30\% coarse-grained (fine pebblegravelstone) (> $2 \mathrm{~mm}), 40-50 \%$ large-grained $(2-0.5 \mathrm{~mm}), 10 \%$ medium-grained $(0.5-0.25$ $\mathrm{mm})$, and $15-24 \%$ fine-grained $(0.25-0.05 \mathrm{~mm})$ fractions. The content of silt fraction $(0.05-$ $0.005 \mathrm{~mm}$ ) does not exceed $6.5 \%$, and that of clay fraction, $8 \%$. In the roof of the unit, the content of coarse-grained fraction drastically increases to $52 \%$, that of large-grained fraction remains the same $(40 \%)$, and the contents of medium-grained, fine-grained, silt, and clay fractions decrease to $4.6,1,1$, and $1.3 \%$, respectively. The content of quartz in the light fraction slightly increases from base to roof (up to 50\%) of the unit, whereas other minerals: plagioclases $(20-28 \%)$ and K-feldspars $(25-40 \%)$ are evenly distributed throughout the analyzed moraine section. The fraction also contains rock fragments (3-6\%). Deposits with this mineralogical composition are referred to as arkoses. Mineral composition of the heavy fraction almost does not change throughout the rock unit (magnetite-amphibole association); the contents of minerals are variable: magnetite 3-30\%, amphiboles $55-80 \%$, and ilmenite, rutile, epidote, and sphene $2-5 \%$ each. Moreover, occasional shows of garnets, zircon, pyroxenes, siderite, goethite, hematite, leucoxene, fluorite, biotite, tourmaline, staurolite, and sillimanite (portions of percent) are present. All mineral grains are angular or angular-rounded. The above data on the lithology of the Del'bichinda unit overlying granitoids of the Upper Proterozoic Irel' complex indicate that the unit resulted from the exaration of mainly amphibolites of the Lower Proterozoic Ilikta Formation widespread on the Baikal Ridge peaks. Similar deposits were found in terminal moraines $10 \mathrm{~km}$ from the mouth of the Minya River and in other areas, but the most complex section of morainic deposits was revealed in the Okunaika River valley. Here, the steep scarp is composed of 


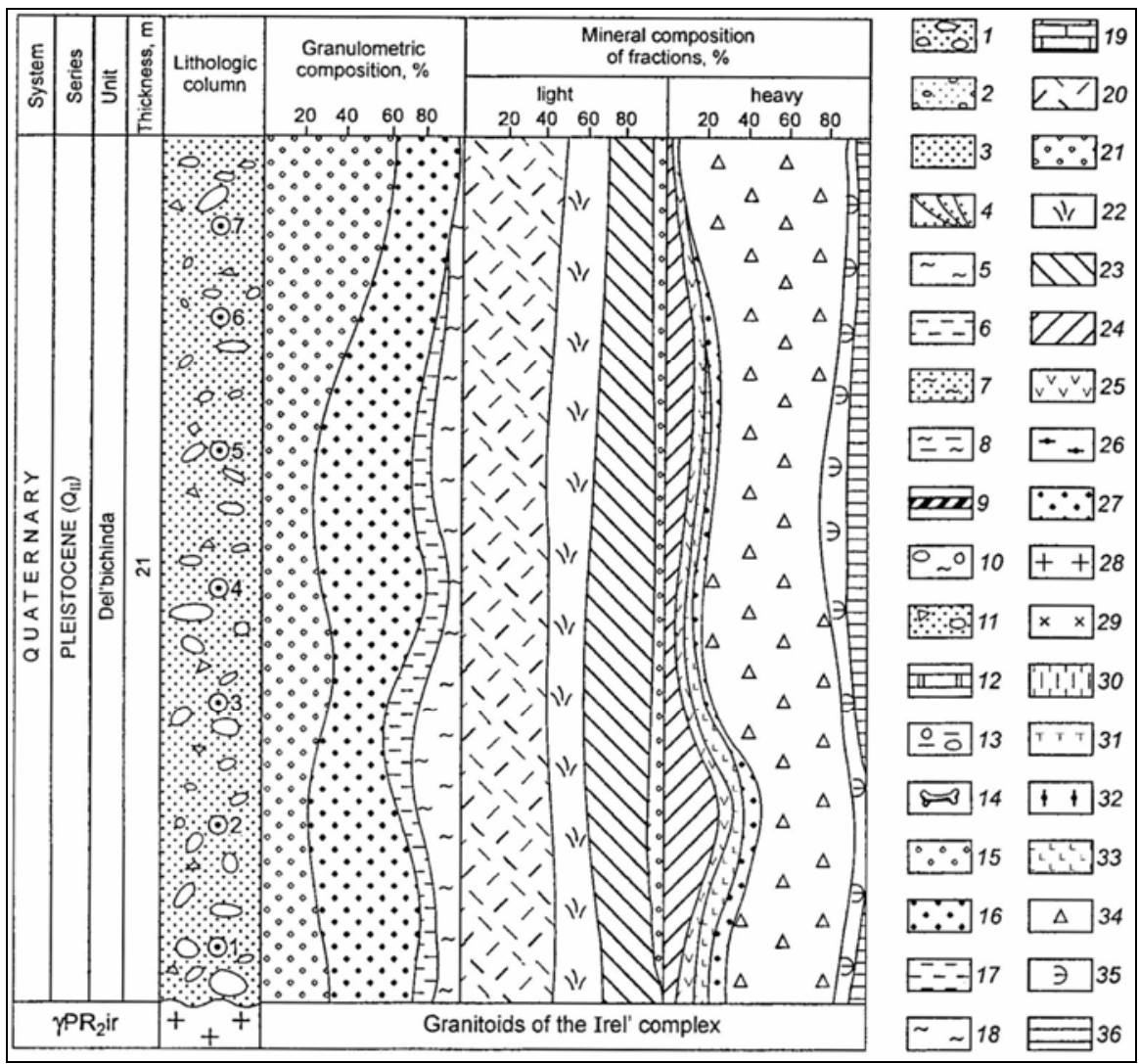

Fig. 6. Lithologo-stratigraphic section of morainic deposits (Del'bichinda rock unit; Northwestern glaciation unit).Circles with points and digits in lithologic columns mark sampling localities. 1-13 - deposits: 1 - sand-boulder-pebble, 2 - sand-pebble, 3 - sands, 4 layered sands, 5 - clays, 6 - silts, 7 - sandy loams, 8 - loams, 9 - cuirasse, 10 - clays with boulders and pebbles, 11 - sand-debris-pebble, 12 - buried soils, 13 - loams with gruss and pebble; 14 - bones of a large mammal; 15-19 - granulometric composition (fractions, $\mathrm{mm}$ ): 15 $>2,16$ - 2- 0.5, $17-0.5-0.25,18-0.25-0.1,19-<0.1 ; 20-23$ - mineral composition of light fraction: 20 - quartz, 21 - rock fragments, 22 - plagioclases, 23 - K-feldspars; 24-36 - mineral composition of heavy fraction: 24 - magnetite, 25 - ilmenite, 26 - zircon, 27 - rutile, 28 leucoxene, 29 - siderite, 30 - sphene, 31 - tourmaline, 32 - psilomelane, 33 - goethite, 34 amphiboles, 35 - epidotites, 36 - apatite.

boulders and pebbles with yellowish-gray sandy loam filling all the space around the psephitic material. In petrographic composition (granitoids, felsitic porphyry, graniteporphyry, quartzites, limestones, dolomites) these deposits are identical to Lower Devonian pebbles and boulders of the Ornochekan Formation. Exaration and subsequent redeposition of boulder-hosting red-colored poorly cemented conglomerates of the Ornochekan Formation took place over a vast area covering the northwestern part of the Cisbaikalian basin. The area of preserved relics of these conglomerates reaches $25 \mathrm{~km}^{2}$. The absence of 
scores, furrows, and other traces of glacier activity from rock blocks and boulders from morainic deposits is due to the fact that the creeping mountain glaciers eroded exposing red-colored boulders and pebbles that were well rounded in the Baikal paleobasin in the Early Devonian (Akulov, 2004). Owing to the good roundness, the boulders and pebbles easily rolled and were less subject to abrasion. Possibly, part of boulders and pebbles with glacier scores is buried in the lower moraine horizons. We investigated the morainic and fluvioglacial deposits also in the southern part of the Baikal depression (the southern block of glaciation at Baikal) on the northwestern arms of the Khamar-Daban Range. The ground moraine from the Mid-Pleistocene glaciation up to $12 \mathrm{~m}$ in visible thickness is detected here under the layer of fluvioglacial pebbles. It is traceable as far as nearly the littoral zone of Lake Baikal (Figs. 7-9). Exaration caused by glaciers moving along mountain slopes and ancient river valleys led to the formation of ice-dressed rocks and glacier furrows and polishing on Proterozoic magmatic and metamorphic bedrocks. Results of this process are seen almost everywhere on the exposed steep $\left(\geq 40^{\circ}\right)$ slopes of the Khamar-Daban, Akitkan and Baikal Ridges. In the rear of the terminal-moraine bars in the middle course of the Minya River, upper reaches of the Domutka River, and other areas glacier-dammed lakes appeared, which are now filled with terrigenous sediments and are vast bogs. A series of lakes, though much smaller, also formed along the leading edge of segment-like moraine bars. It is here that fluvioglacial deposits begin, extending from terminal-moraine bars for almost $20 \mathrm{~km}$ to the west; they occupy an area of more than $200 \mathrm{~km}^{2}$. Farther westward from the Akitkan and Baikal Ridges, the thickness of fluvioglacial deposits gradually decreases up to their vanishing near the Kirenga River valley (Fig. 10-11).

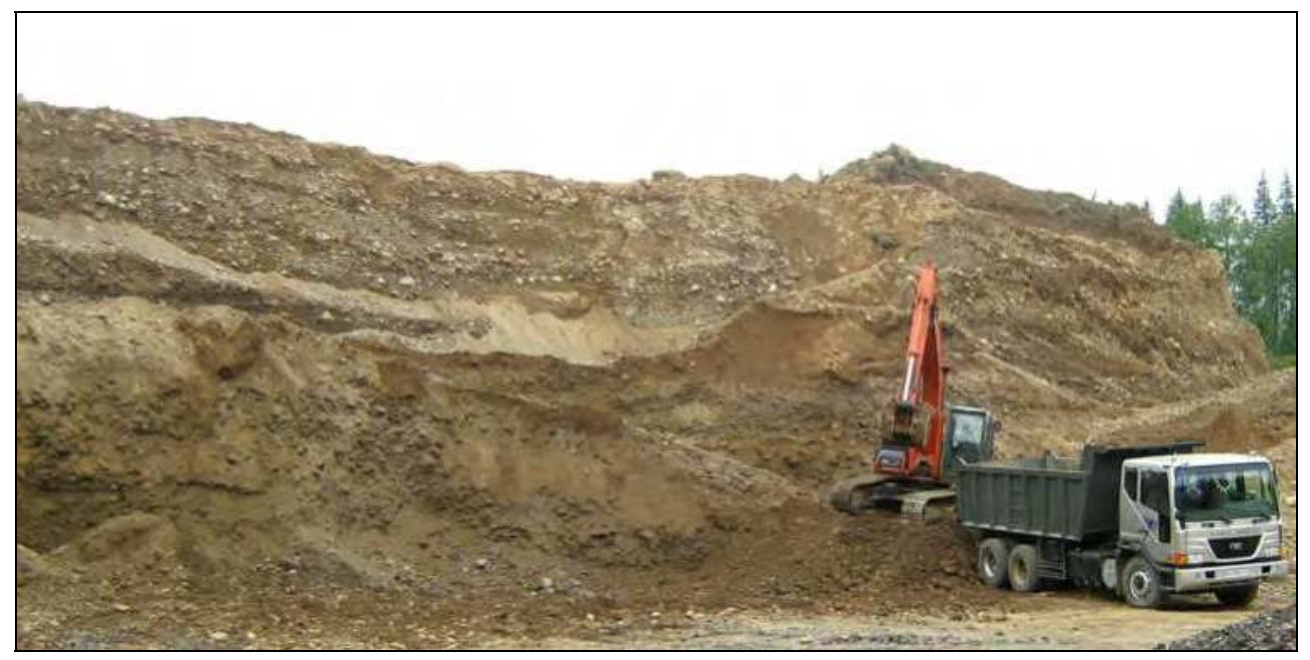

Fig. 7. Glacial deposits of the middle part of the morainic complex. Southeastern glaciations unit; mining open cast in the area of the settlement of Vydrino.

\subsection{Aqueoglacial deposits}

Aqueoglacial deposits are subdivided into river glacial (fluvioglacial), mud-fluvioglacial, and glaciolacustrine. By the type of formation, glaciolacustrine deposits are subdivided into 
periglacial and intraglacial. In the case of periglacial deposits, the relief after the end of glaciation and disappearance of glaciers is formed by glaciolacustrine plains (outwash plains) and small, extending for 5-6 km along the glacier path, elongate-oval hills (radial oses). In the case of intraglacial deposits, the relief is formed by rounded conical domes with flat tops - kames. In radial oses, the long axis of hills coincides with the direction of the movement of fluvioglacial streams $\left(250^{\circ} \mathrm{SW}\right)$. Their relics are localized in watersheds of rivers that deeply separated the postglacial relief, which gave grounds to refer them to "watershed pebbles". One of such sites is the mouth of the Okunaika (right tributary of the Kirenga River), where morainic deposits rise above the river level to almost $60 \mathrm{~m}$. Adamenko et al. (1974), who studied such deposits near the mouth of the Baldakhin'ya River (left tributary of the Kirenga), called them the Ul'kan fluvioglacial rock unit. They separated the unit into three members (from bottom to top):

1. Reddish-gray sands with horizontal and oblique layering

Thickness, $\mathrm{m}$

10.0

. Red-brown clays with banded layering 18.0

3. Red-cherry clays with boulders and rock blocks $0.2-0.3$ tons in weight 15.0 Soil-vegetation layer

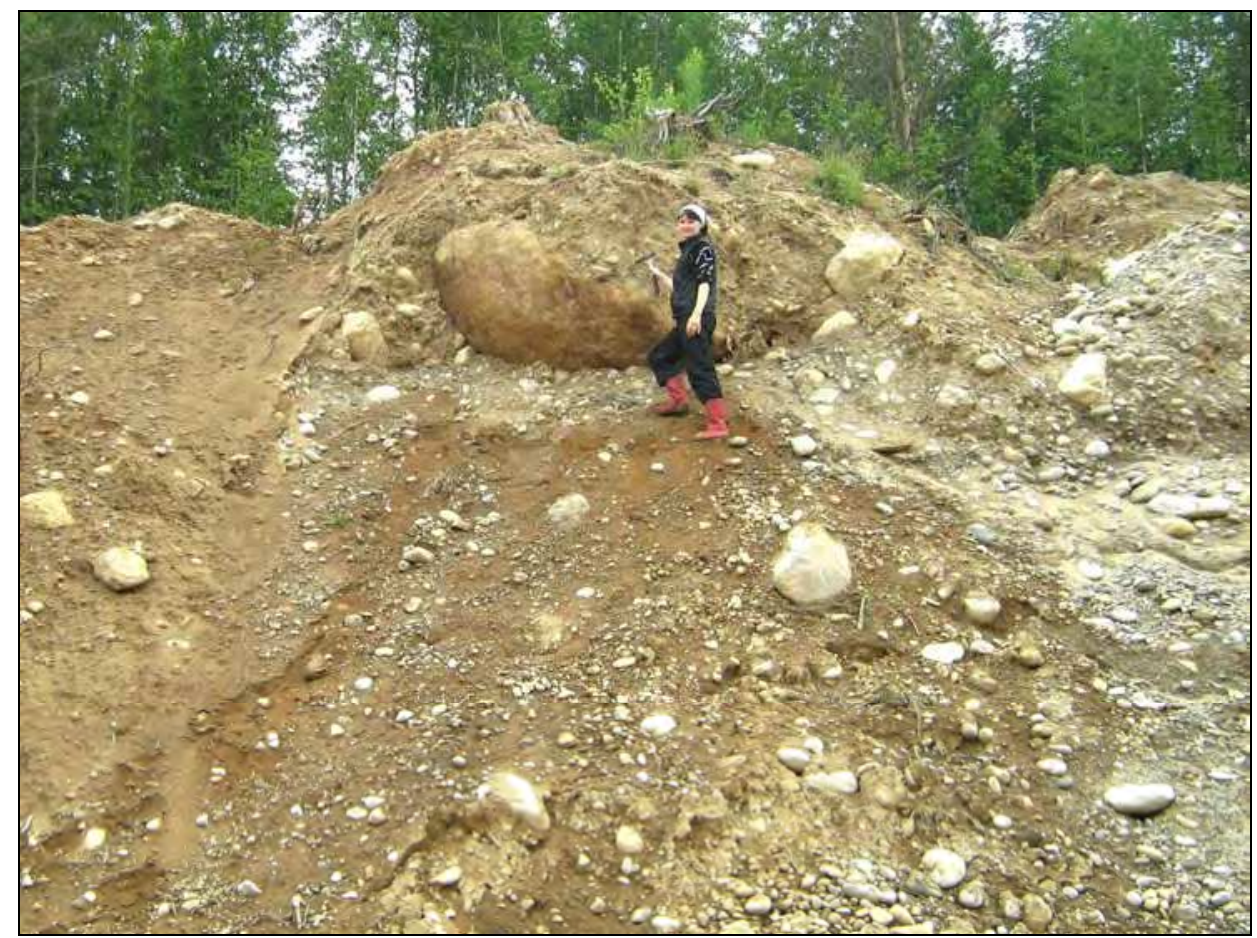

Fig. 8. Well-rounded erratic block $1.6 \times 3.2 \mathrm{~m}$ in size as part of morainic deposits (Southeasetrn glaciations unit; $3.2 \mathrm{~km}$ to the south of the settlement of Vydrino). 
Our research has shown that only deposits of member 3 are properly fluvioglacial. The other two members formed in the preglacial warm epoch. This is evidenced from their lithology and spore-and-pollen complexes discovered in varved clays of member 2. Palynological analyses carried out by L.M. Shestakova and L.A. Filimonova showed that the clays contain pollen of broad-leaved trees (oak, hazel, etc.). Moreover, red-brown loams of the same member have preserved bone fragments, which, according to L.N. Ivan'ev, are parts of radius and pelvic bones of a large mammal Elephas sp. (s. 1) inhabiting this area in the Pleistocene preglacial epoch (Adamenko et al., 1974; Kul'chitsky, 1973). Therefore, only boulder-block clays (member 3) should be referred to as fluvioglacial deposits of the Ul'kan rock unit. On geological mapping (scale $1: 200,000$ ) all Cenozoic preglacial deposits to the Chingor rock unit $\left(\mathrm{N}_{2}-\mathrm{Q}_{1}\right.$ - Pliocene-Lower Quaternary deposits). The deposits consist of yellowish-gray gravel, brown clays, gray sands, and grayish-brown loams. Thus, deposits of members 2 and 3 are similar to the Chingor unit. In some quarries, gravel-pebble deposits of the Chingor unit resulted from the erosion and redeposition of earlier weathered gravel and pebble and products of Cretaceous-Paleogene crust of weathering. This is evidenced from the fact that the unit contains almost evenly distributed (about $30 \%$ of the total volume of terrigenous material) white kaolinitized pebble, lenses of monomict quartz sands, and white kaolin, which imparts a whitish tint to its grayish-yellow deposits. Preglacial deposits of the upper member of the Chingor unit, considered by Adamenko et al. (1974) as glacial, have quite different lithologic properties. We comprehensively studied them in quarry 1 located $1.5 \mathrm{~km}$ from the left bank of the Baldakhin'ya River and $2.5 \mathrm{~km}$ from its meeting with the Kirenga River. These deposits are eroded and overlie the Lower Ordovician limestones of the Ust'kut Formation (Fig. 12) in the sequence (from bottom to top):

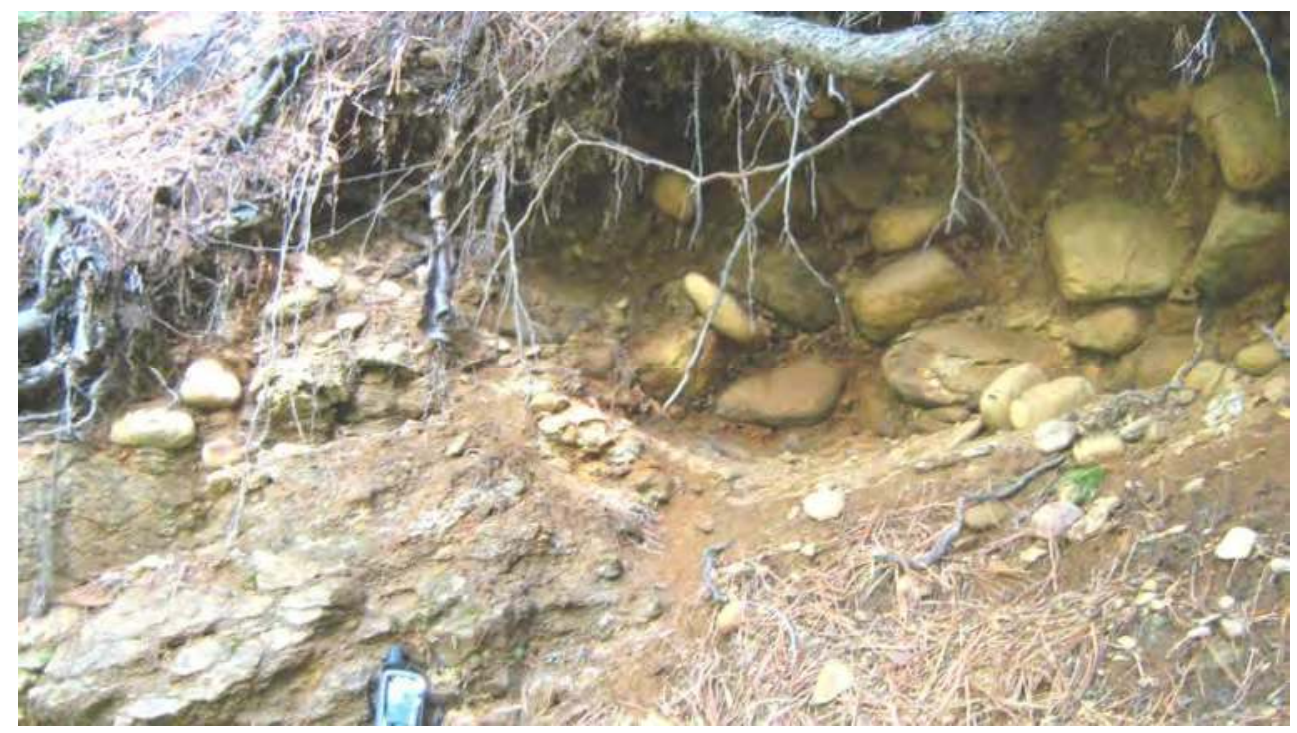

Fig. 9. Bedding conditions of morainic deposits (via plucking) on granitoids of KhamarDaban. On the GPS image, they lie on bedrocks represented by granitoids (southwestern glaciations unit; right bank of the Osinovka River, $6 \mathrm{~km}$ to the south-east of the settlement of Tankhoi). 
Thickness, $\mathrm{m}$

1. Well-washed and well-sorted brownish-gray gravel with low-angle cross bedding

2. Light-gray massive loam

3. Well-washed and well-sorted light-yellow fine-grained polymict obliquely laminated sand

4. Poorly washed gray massive gravel

5. Light-gray fine-grained quartz sand with low-angle cross bedding

6. Poorly washed gray massive gravel

7. Gray inequigranular (large- and medium-grained) sand

8. Whitish-yellow horizontally laminated clay

9. Dark-yellow horizontally laminated fine-grained sand with a thin $(4 \mathrm{~cm})$ cuirasse parting in the bed roof

Total thickness of stripped deposits

The low-angle cross bedding and high degree of grading and washing of the psammitic material evidence its accumulation in lake-delta environments with warm humid climate. The age of the rock unit was determined from analysis of the spore-and-pollen complex, which includes Abies sp., Tsuga sp., T. diversifolia, Picea sp., Larix sp., Pinus diploxylon, smallleaved pollen Betula sp. and Alnus sp., occasional broad-leaved pollen Corylus sp., Tuglans sp. and Quercus sp. pollen. Grass pollen is abundant (Artemisia sp., Gramineae sp., etc.). Also, exotic coniferous Pinus haploxylon and $P$. strobes were found. The spore-and-pollen complex is dominated by pollen of the family Pinecede (55-69\%). The composition of this complex gives no grounds to date the hosting deposits of the Chingor unit to the Pliocene-Early Eopleistocene. Granulometric analysis of the gravel deposits showed that the content of coarse-grained material in them gradually decreases from base (sample 13; 40\%) to roof (sample 4; 9\%) of the rock unit, whereas the contents of large-, medium-, and fine-grained fractions increase. The main mineral of the light fraction of gravel and sandy deposits is quartz (55-90\%); plagioclases and K-feldspars amount to no more than $2 \%$. The remainder of the fraction is rock fragments. The mineral composition of the fraction permits us to refer the deposits to siliceous clastites and quartzy rocks. The mineral composition of the heavy fraction is the same almost over the entire section: zircon $(22-52 \%)$, rutile $(4-16 \%)$, and leucoxene (23-38\%). The lower beds of the section also contain psilomelane, whose content decreases from basal horizon $(42 \%)$ to middle part $(2.8 \%)$ of the Chingor unit. The upper beds bear tourmaline (up to $8 \%$ ) and ilmenite (up to 7\%). Magnetite, garnets, sphene, brookite, amphiboles (hornblende, tremolite, actinolite), pyroxenes, disthene, staurolite, siderite, goethite, and pyrite are minor (no more than portions of percent). Note that all types of studied deposits bear a rare mineral - florencite, whose content increases from occasional shows in the roof to $1.4 \%$ in the base of the section. The grains of all minerals are well rounded; only quartz grains and rock fragments of the light fraction are angularrounded. It is important to emphasize that the above-mentioned deposits are overlain with erosion by rather uniform massive reddish-brown fluvioglacial clays with boulders (boulder clays) amounting to about $10 \mathrm{vol}$. \% of the rock. The boulders are perfectly rounded; these are granitoids and felsitic porphyry. They are of equal size, mainly no larger than $29 \times 27 \times 19$ $\mathrm{cm}$. These clays reach $1.6 \mathrm{~m}$ in thickness. They are similar to the above-described fluvioglacial deposits of the Ul'kan Formation. Mineralogical analysis showed that the clays differ considerably from the underlying deposits in the mineral composition of heavy 
fraction (goethite-zircon assemblage): goethite $(23.8 \%)$, siderite $(10.2 \%)$, sphene $(8.4 \%)$, florencite $(0.2 \%)$, zircon $(26.8 \%)$, magnetite $(8.6 \%)$, ilmenite $(8.8 \%)$, rutile $(7 \%)$, epidote $(1.6 \%)$, tourmaline $(1.6 \%)$, and hornblende $(0.8 \%)$. As in the underlying deposits, the light fraction of the above clays is dominated by quartz $(84.4 \%)$, the remainder being rock fragments (9.6\%). Similar composition of the light fraction was observed in the underlying siliceous clastites and quartzy rocks of the Chingor unit. In addition, the fraction contains plagioclases $(5 \%)$, K-feldspars $(0.6 \%)$, muscovite $(0.3 \%)$, and carbonized plant remains $(0.1 \% 0$. The mineral grains are angular-rounded. Granulometric analysis of the rock fragments separated through the water washing of the clay fraction showed the following composition of the terrigenous material: coarse-grained 20\%, large-grained - 32\%, medium-grained - $14 \%$, and fine-grained - the balance. The boulder-clayey deposits seem to have formed during the intense thawing of glaciers, which gave rise to strong mud flows in vast areas.

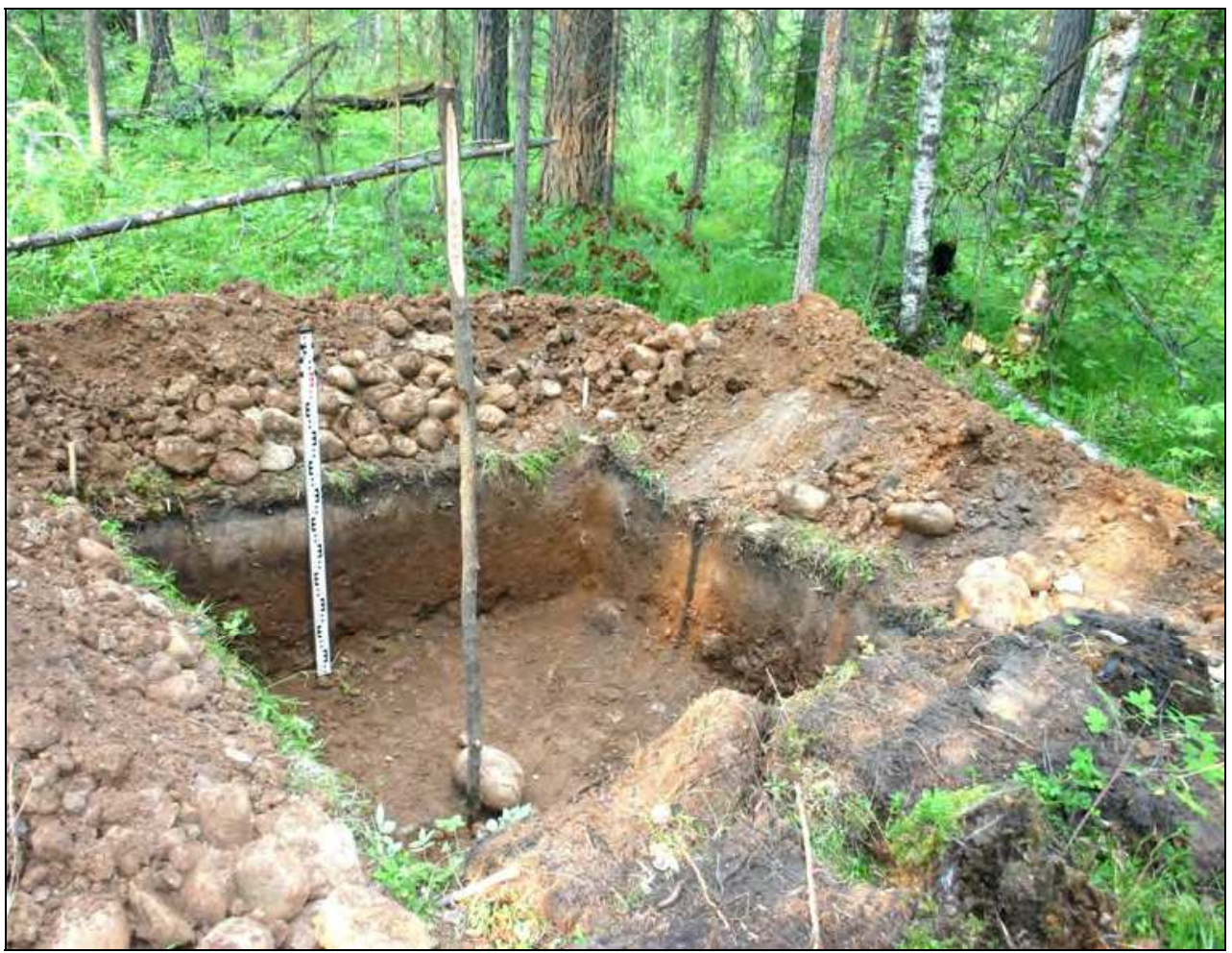

Fig. 10. Morainic boulder-block-pebble deposits in clayey cement. Northwestern glaciations unit; pit No. 64 is located in the mouth zone of the Minya River (the right tributary of the Kirenga River). 


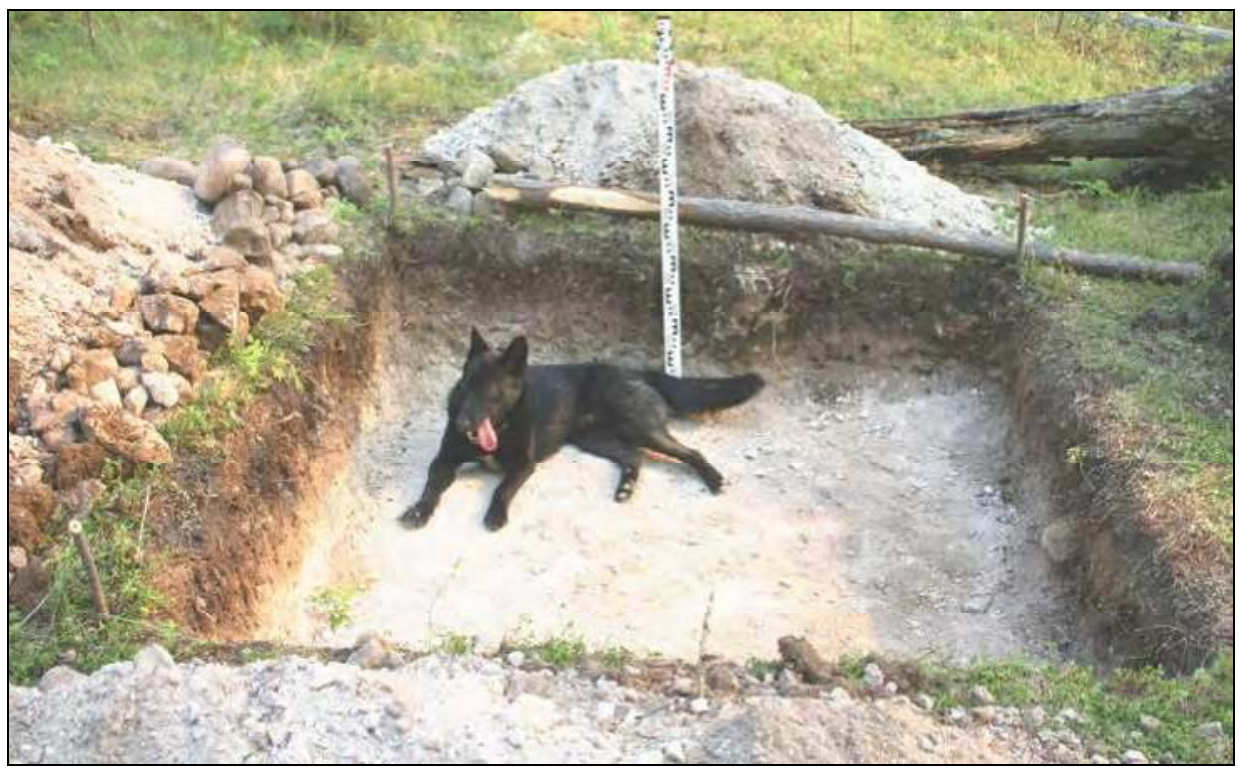

Fig. 11. Marginal part of glaciations or boundary of glacial rafting of boulders and pebbles occurring on products of physical weathering of dolomites of the Ust'-Kut formation. Northwestern glaciations unit; pit No. 79 is located on the left bank of the Kirenga River in the area of the settlement of Kazachenskoye.

\subsection{Mud-fluvioglacial deposits}

Mud-fluvioglacial deposits about $1.5 \mathrm{~m}$ thick lie over the Chingor unit or the Middle-Upper Cambrian red-colored mudstones of the Upper Lena Formation. Such deposits were also stripped on the left bank of the Kirenga River. They are composed of red-colored or lightbrown supersticky clay hosing mainly well-rounded boulders and occasional pebbles. The red color of the deposits is due to the presence of erosion products of the underlying bedrocks of the Upper Lena Formation. Obviously, some fluvioglacial streams crossed the Kirenga River bed. In the pit on the slope of the left Kirenga bank (opposite the Okunaika mouth), at a height of $150 \mathrm{~m}$ above the river level, the following deposits were stripped (from base to top):

Thickness, $\mathrm{m}$

1. Red-colored mudstones with horizontal layering $\quad>0.35$

2. Brown-gray boulder-debris-clayey deposits 0.3

3. Light-brown boulder-debris-loam deposits 0.15

4. Brownish-gray loams with gruss and pebble $\quad 0.65$

5. Light-gray sandy loam $\quad 0.15$

$\begin{array}{lr}\text { Soil-vegetation layer } & 0.05\end{array}$

Proper mud-fluvioglacial deposits occur in beds 2 and 3. Angular fragments among them are local limestones and sandstones of the Ust'kut Formation. The deposits also abound in

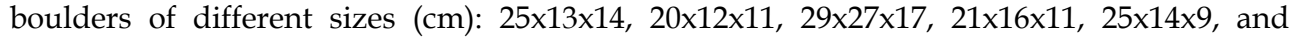


24x17x13. They are mainly of granitoid composition: granite-porphyry, sheared granites, granodiorite-porphyry, and blastomylonite granites. Effusive rocks are scarce. The rock grains are well rounded. Granite-porphyry is of holocrystalline texture. Some large $(2-4 \mathrm{~mm})$ feldspar phenocrysts contain altered plagioclase. The groundmass consists of plagioclase, feldspar, quartz, amphibole, chlorite, epidote, apatite, and ore mineral; the latter, like amphibole, forms large (up to $2.5 \mathrm{~mm}$ ) accumulations. Mineralogical analysis of thin sections showed the following composition of granodiorite-porphyry: plagioclase (40-45\%), K-feldspar (20-25\%), quartz (10-20\%), hornblende (10-15\%); accessory minerals are apatite (up to $2 \%$ ), sphene, zircon, titanomagnetite, and, less often, orthite. Boulders in effusive rocks belong to rhyolite-porphyry (liparites) according to their petrographic composition. They have a distinct porphyritic texture, with the groundmass composed of granophyric microgranite. Porphyry phenocrysts consist of plagioclase, feldspar, and quartz. The latter occurs as a short-prismatic crystals, in places intensely corroded. Feldspars and plagioclase are partly replaced by chlorite and carbonate. Chlorite is of radiolith structure. Ore inclusions reach $0.3 \mathrm{~mm}$ in size. The liparite groundmass is of cryptocrystalline texture and, locally, of distinct fluidal structure. The liparite contains inclusions of quartz, K-Na-feldspar, and plagioclase. The high degree of roundness of the rock blocks and boulders unambiguously points to their redeposition from more ancient deposits during the transportation of the latter by waters. The boulders were supplied mainly from the Irel' intrusive complex and Devonian conglomerates of the Ornochekan Formation. Mineralogical analysis of sandy material in boulders and debris of the Okunaika unit showed that the light fraction contains quartz (up to $42 \%$ ), plagioclases (16\%), K-feldspars (8\%), and minerals in rock fragments (up to $45 \%$ ) (Fig. 13). Psammitic deposits with a similar mineral composition of light fraction are usually called feldspathic-quartz graywackes. Minerals of the heavy fraction are magnetite (37\%), amphiboles (28\%), ilmenite $(23 \%)$, zircon $(12 \%)$, and epidote $(\sim 8 \%)$. Also, minor (no more than portions of percent) garnets, sphene, pyroxenes, apatite, tourmaline, florencite, goethite, and hematite are present. All grains are rounded or angular-rounded. We performed a spore-and-pollen analysis of samples taken from bed 2 of the above-described section of loose deposits. Three samples are dominated by pollen of tree species (52-87\%), mainly coniferous: pine (Pinus sylvestris) - 30-55\%, cedar (Pinus sibirica) $-23 \%$, spruce (Picea obovata) $-4-7 \%$, and fir (Abies sibirica). Deciduous trees are represented by occasional pollen of alder (Alnus) and birch (Betula secs. Albae). Pollen of bushes is minor and includes cedar elfin wood (Pinus pumila), shrubby birch (Betula secs. Nanae), and Duschekia (Duschekia). Two samples from the lower beds (depths 0.6-0.9 m) abound in pollen of grasses, particularly wormwood (Artemisia), and the third sample from the upper bed, in moss spores (Lycopodium sp.), including coniferous species L. clavatum, L. annotinum, and L. complanatum, as well as grape fern (Botrychium, growing on taluses and debris substrates) and ferns (Polypodiaceae). The lower samples (0.6-0.9 m) exhibit a considerable role played by pollen of grasses, especially wormwood (Artemisia), while clubmoss (Lycopodium sp.) spores are dominant in the upper samples. The spore-and-pollen spectra show that the area was earlier inhabited by cedar-pine forests including spruce, fir, and, seldom, alder and birch. Bushes and grasses were scarce. There were also open sites such as taluses and slightly turf-covered debris slopes. The great number of forest moss species and decrease in the portion of tree species (52\%) in the upper part of the section might indicate the presence of larch in the forests, whose pollen has been poorly preserved. The plants revealed in this section evolved, most likely, in the Late Pleistocene or early Early Holocene. Thus, the studied mud-fluvioglacial deposits correspond in the time of formation 
to the Sartan (Q4 ${ }^{4}$ II) Glaciation in West Siberia, i.e., to the Late Würm (Würm III) according to the Alpine Stratigraphic Chart. It is important to note that a bone of large mammal was found in brownish-gray loams of bed 4 . In similar deposits stripped during archaeological excavation in the Baldakhin'ya-Tala watershed (exc. 1), a broken bone, fragments of ceramic vessels, and abundant flakes were discovered (Fig. 14).

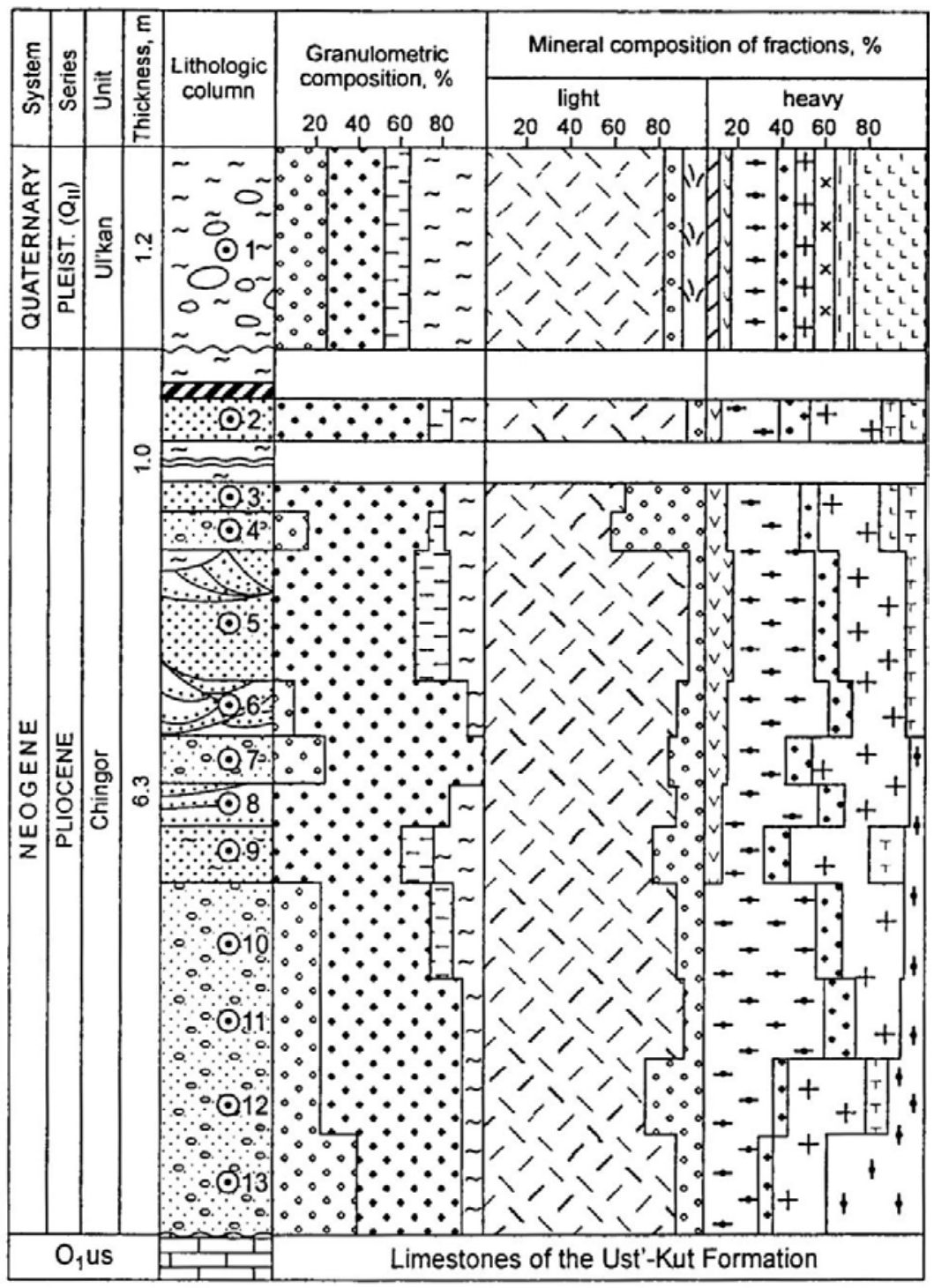

Fig. 12. Lithologo-stratigraphic section of preglacial (Chingor unit) and fluvioglacial (Ul'kan unit) deposits (quarry 1). The designations are the same as in Fig. 6. Northwestern glaciations unit. 


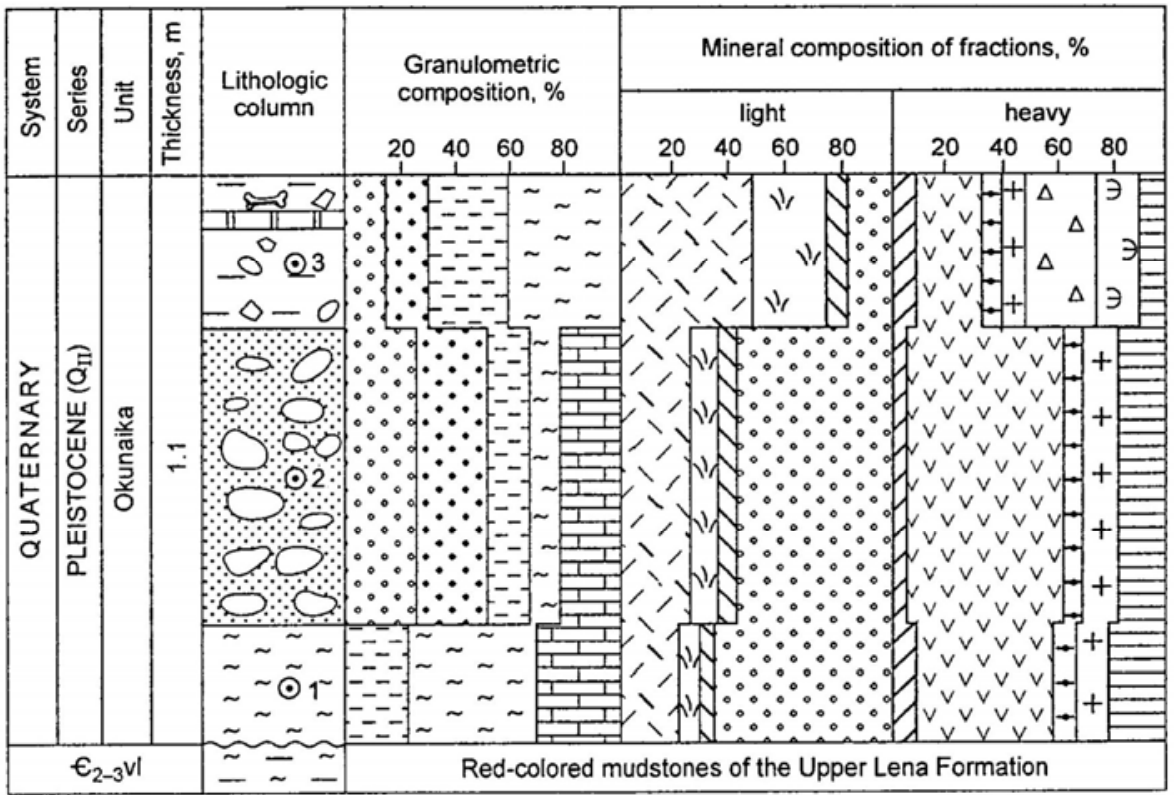

Fig. 13. Lithologo-stratigraphic section of the Okunaika unit, pit No. 62. The designations are the same as in Fig. 6. Northwestern glaciations unit.

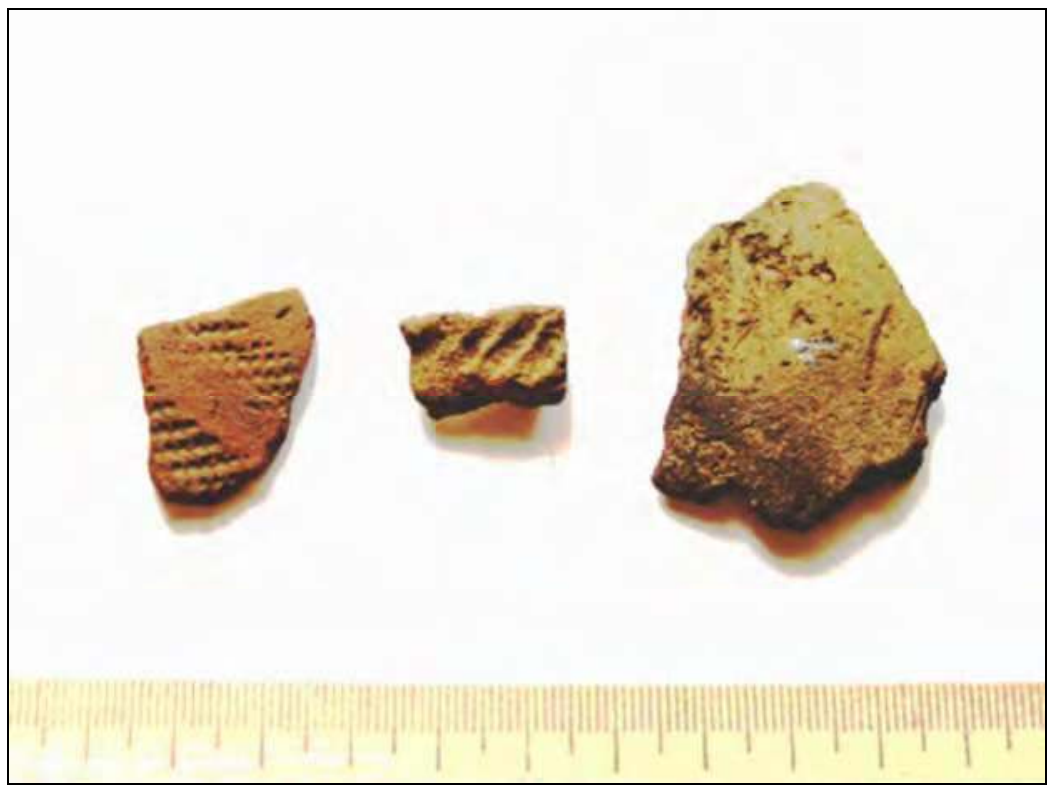

Fig. 14. Fragments of ceramics from the first layer having preserved archaeological cultural specimens in excavation 1 (vicinity of the Okunaika mouth). Northwestern glaciations unit. 


\subsection{Fluvioglacial deposits}

Fluvioglacial deposits are widespread on the right bank of the Kirenga River, in the vicinity of the mouths of its right tributaries Okunaika, Umbella, Minya, and Kutima (Fig. 15). These are sandy-pebble deposits containing well-rounded boulders and rock blocks. The blocks reach $2.1 \mathrm{~m}$ in size along the long axis. The average size of boulders is $23 \times 20 \times 16 \mathrm{~cm}$, and that of pebbles, $5 \times 3 \times 2 \mathrm{~cm}$. Blocks amount to $\sim 5$ vol. \%; boulders, 10 vol. \%; pebble, up to 40 vol. $\%$; the remainder is inequigranular sand. The boulders and blocks are composed mainly of granitoids. The deposits are yellowish-gray, poorly sorted, with horizontal and low-angle cross bedding. The inequigranular sands are quartz graywackes: They consist of quartz $(27 \%)$, plagioclases $(6 \%)$, and rock fragments $(77 \%)$. Minerals of the heavy fraction are ilmenite $(58 \%)$, apatite $(21 \%)$, leucoxene $(12 \%)$, zircon $(6 \%)$, and the rest $(3 \%)$ is amphiboles, magnetite, Cr-spinellide, siderite, florencite, tourmaline, rutile, hematite, and goethite. Fluvioglacial deposits are best exposed near the mouth of the Umbella River. Zamaraev et al. (1976) reported on exposed horizontally layered pebbles alternating with clay-silty deposits and sands formed during the thawing of glaciers in the terminal-moraine area. These exposures were observed in a 50-55 m high scarp beneath yellowish-gray $1.5 \mathrm{~m}$ thick loess-like loams. The researchers suggested that the glaciers formed at the peak of the Samarovo Glaciation ( $\mathrm{Q}^{2}$ III). The morainic deposits are block-boulder accumulations with psammite-clay filler. Sand-clayey fluvioglacial deposits contain spores and pollen typical ofpine-birch forests including alder, willow, and minor herbs (data provided by M.V. Litvinova). Before we proceed further upon considering our identified genetic types of glaciation-associated deposits, it would be of interest to at least briefly run through the glaciodislocations caused by the thawing out of blocks of "dead" ice and by subsequent deformations having a subsidence and landsliding character. At the present time, such deposits usually form at the edge of retreating glaciers in the periglacial zone (Fig. 16). Of particular interest are the glacial dikes or glacial injections resulting from pressure of the ice on deposits of the palaeolake. In such cases there is taking place the squeezing-out of lacustrine deposits into cracks and weakened portions of the lower layers of dead ice (Fig. 17). Furthermore, the glaciations were accompanied by an aridization of the climate, and by an intensification of wind activity. The climate aridization was proceeding through the freezing out of moisture from air currents and deposition of hoarfrost on glaciers. An intensification in the activity of cold air flows, mixed with warm air flows, caused an enhancement in winds and their constancy thereby contributing to the widespread occurrence of aeolian deposits. It should be noted that the term "cryoaridization" was coined by V.S. Sheinkman (2002a), who maintains that the glaciation process creates the conditions for progressive cryoaridization accompanied by climate drying due to the freezing out of air masses and the transition of moisture at a solid state.

Thus there was taking place a reduction in the supplies of moisture transported to the areas of Siberian glaciation, as it was intercepted by glacial shields situated in northwestern Europe (Sheinkman, 2002). According to data reported in the reference just cited, unlike the northern part of Western Siberia, deep within Siberia the most favorable conditions for the advancement of glaciers existed at the beginning of the Late Pleistocene, and they were enhanced toward the end of the Late Pleistocene. It should be stressed that the climatic fluctuations under consideration are quite well recorded on the isotope-oxygen curve that was constructed on the basis of analyzing the section of bottom sediments from Baikal 


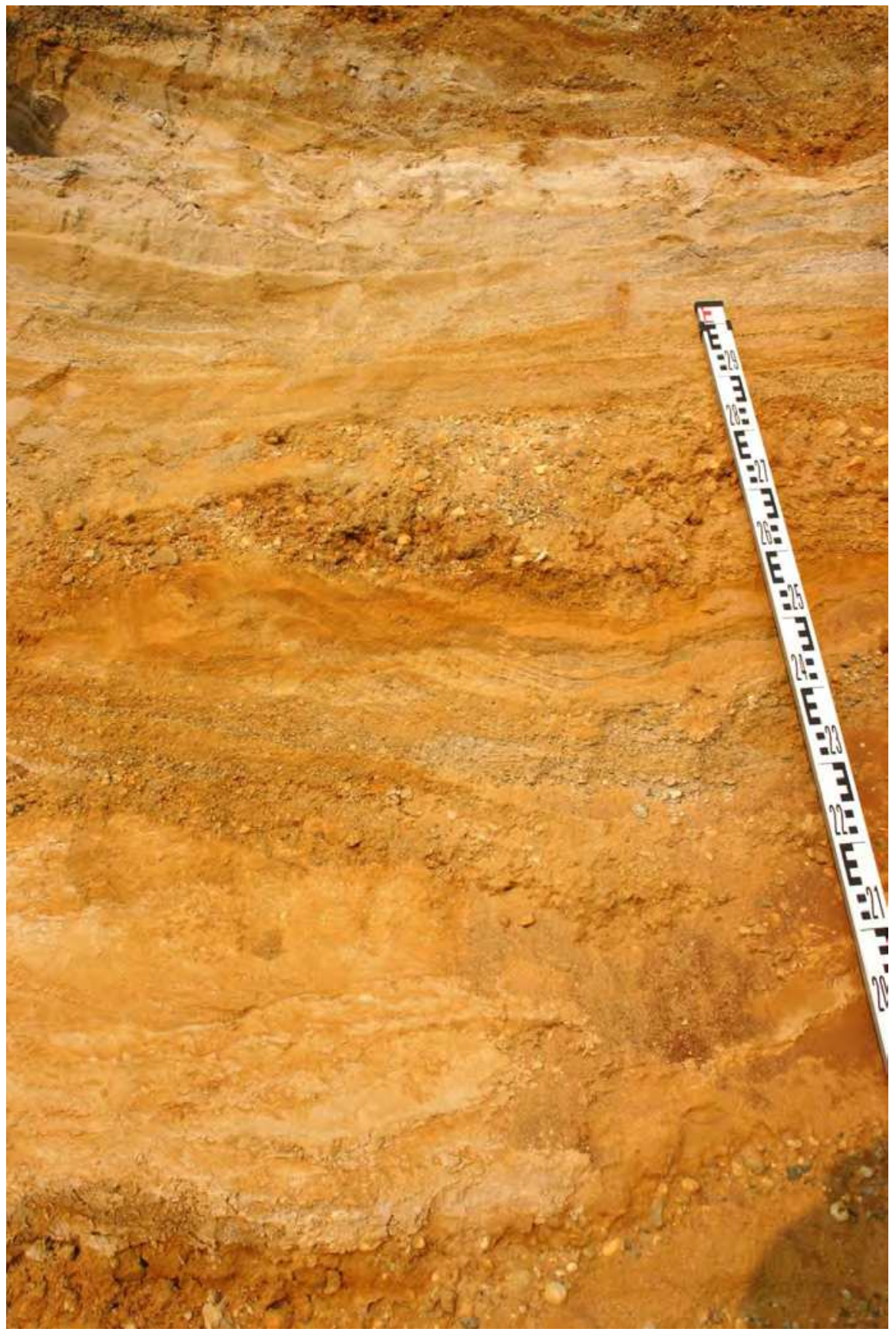

Fig. 15. Gravel-clay-sand fluvioglacial deposits. Northwestern glaciation unit, mining open cast on the right bank of the Umbella River. 

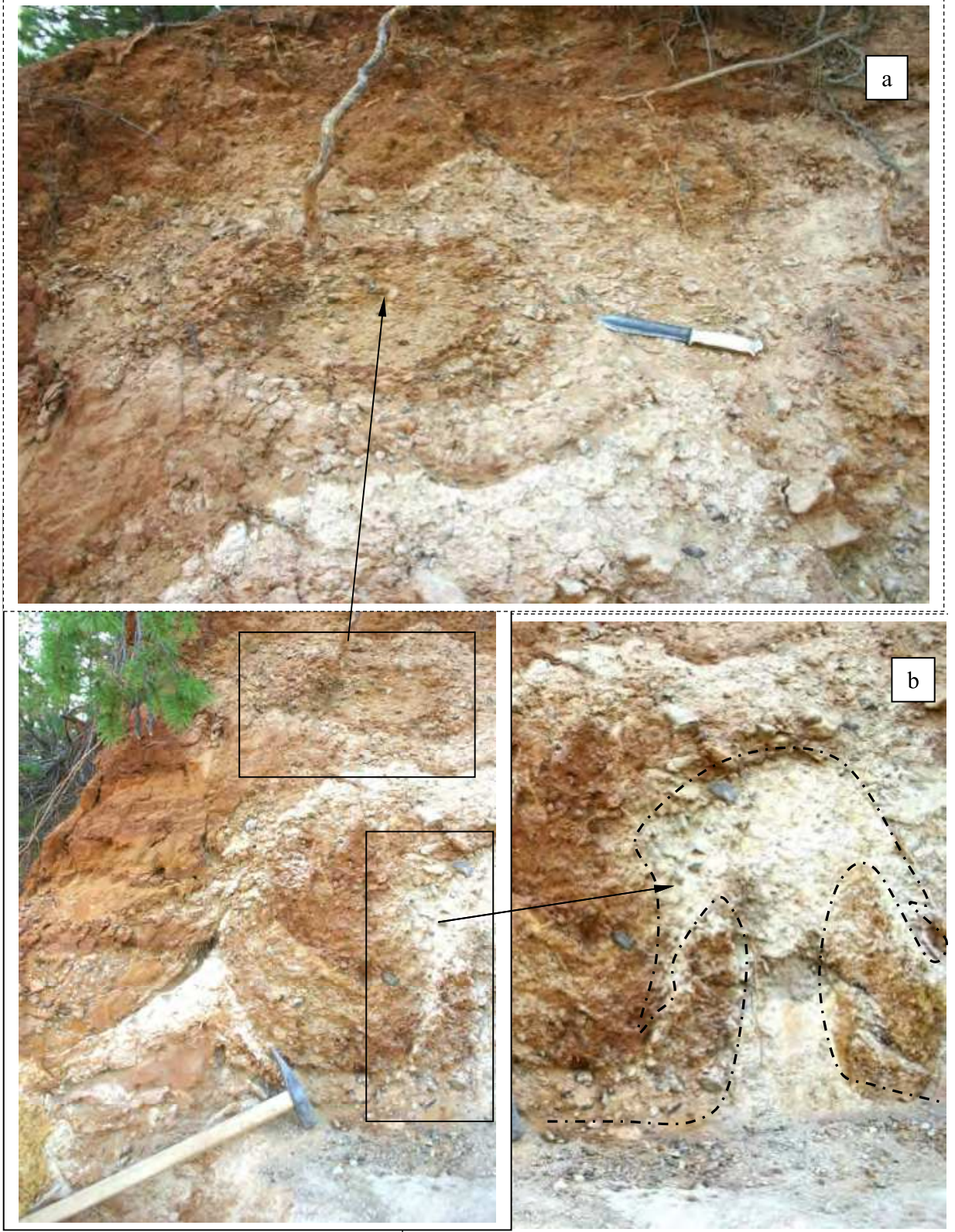

Fig. 16. Glaciodislocations are represented by deformations of subsidence and landslide character. On the fragments: $a$ - perhaps, it is a large layered glacial cotun; b - glacial diapirism or injective form that was produced in the process of squeezing out plastic claylimestone depositions into cracks of the degrading ice. Northwestern glaciations unit; mining open cast in the upper reaches of the Kunerma River. 


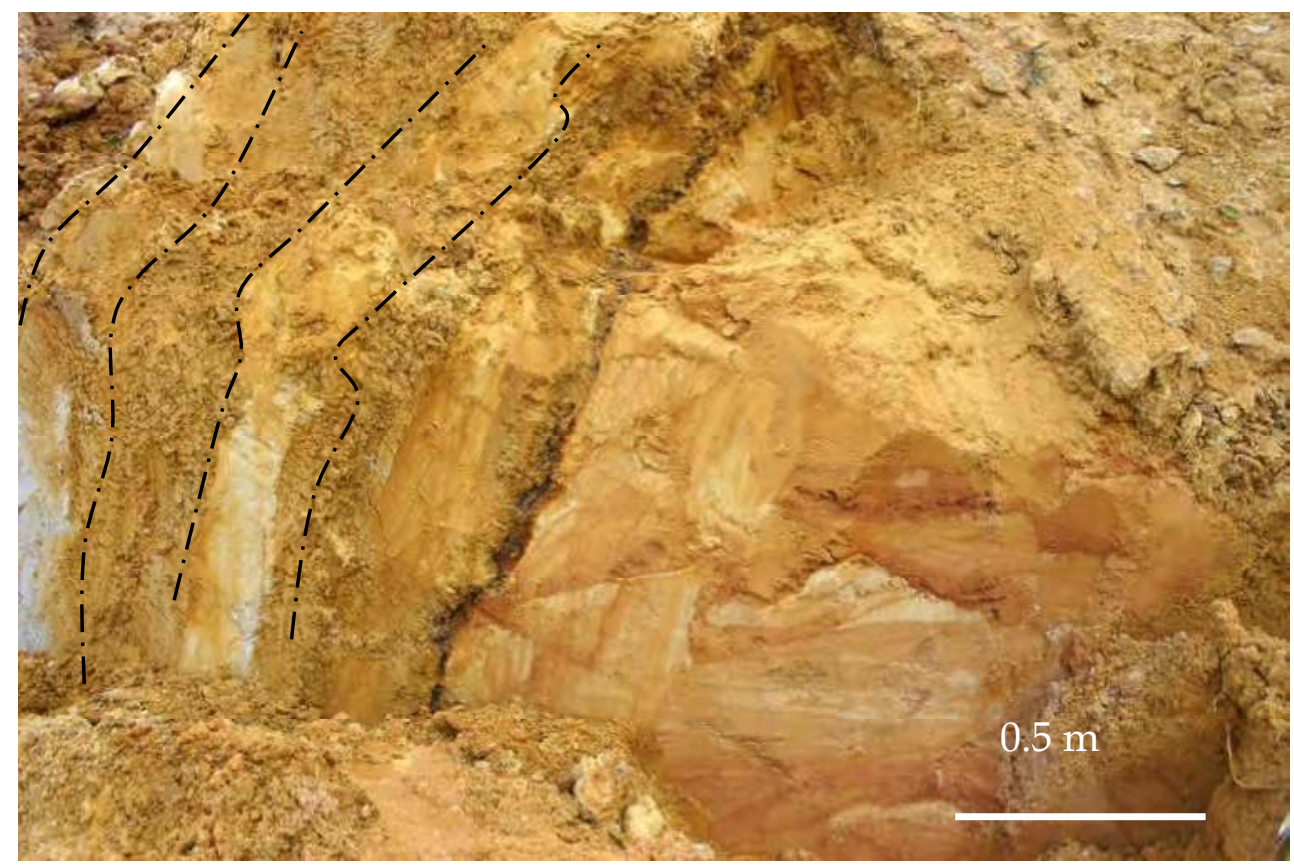

Fig. 17. Glaciodikes or glacial injections resulted from pressure of the ice on deposits of the glacial palaeolake. Northwestern glaciations unit, right bank of the Del'bychindy River.

(Karabanov et al., 1998; 2000). Storm winds are characteristic for the present-day Arctic and Antarctic. Their periphery can include fields of aeolian sands whose formation is possible if the following three conditions are satisfied: 1) dry climate, 2) strong wind, and 3) existence of a sand-producing "factory". The main sand "factories" on Earth are provided by water bodies: oceans, seas, lakes, and rivers. In the littoral parts of water bodies where sand material is being removed to the beach zone, sand undergoes drying $\mathrm{K}$ freezing out; after that, it is captured by storm winds to be transported deep into the continent where it is deposited to form fields of aeolian sands and loessal formations (Akulov et al., 2008; Akulov, Rubtsova, 2011). The widespread occurrence of the subaerial sedimentary formation in regions of manifestation of cryoaridization was pointed out by S.K. Krivonogov (2010). According to data reported by him, a considerable part of sandy massifs in the Charskaya hollow of the Baikal rift system has an aeolian genesis. Previously, there was also no doubt that the sand dunes occurring in the Charskaya hollow have an aeolian genesis. The situation is different with the question: "From where did they originate, given the surrounding mountains only?" It was thought that they were produced by deflation of fluvioglacial and lacustrine-alluvial sediments. According to our data, the sands of the Charskaya hollow emerged in the large barrier palaeolake (Charsky) during the Pleistocene glaciation. It disappeared within several tens of millennia, and the sands that were deflated by it and by the wind have been traveling across the hollow till the present (Akulov, Rubtsova, 2011). Loessal (silty-fine) aeolian sands are of widespread occurrence on the mountain arms of the Baikalsky Range (Fig. 18). Their layer is as thick as three meters. They occur on the exaration surface of granite gneisses, and it is only in the saddles of the relief 
where they are supported by deluvial-proluvial formations very small in thickness (as small as $0.2 \mathrm{~m}$ ). The aeolian silty sands are overlain by a soil-vegetation layer (as thick as $0.2 \mathrm{~m}$ ).

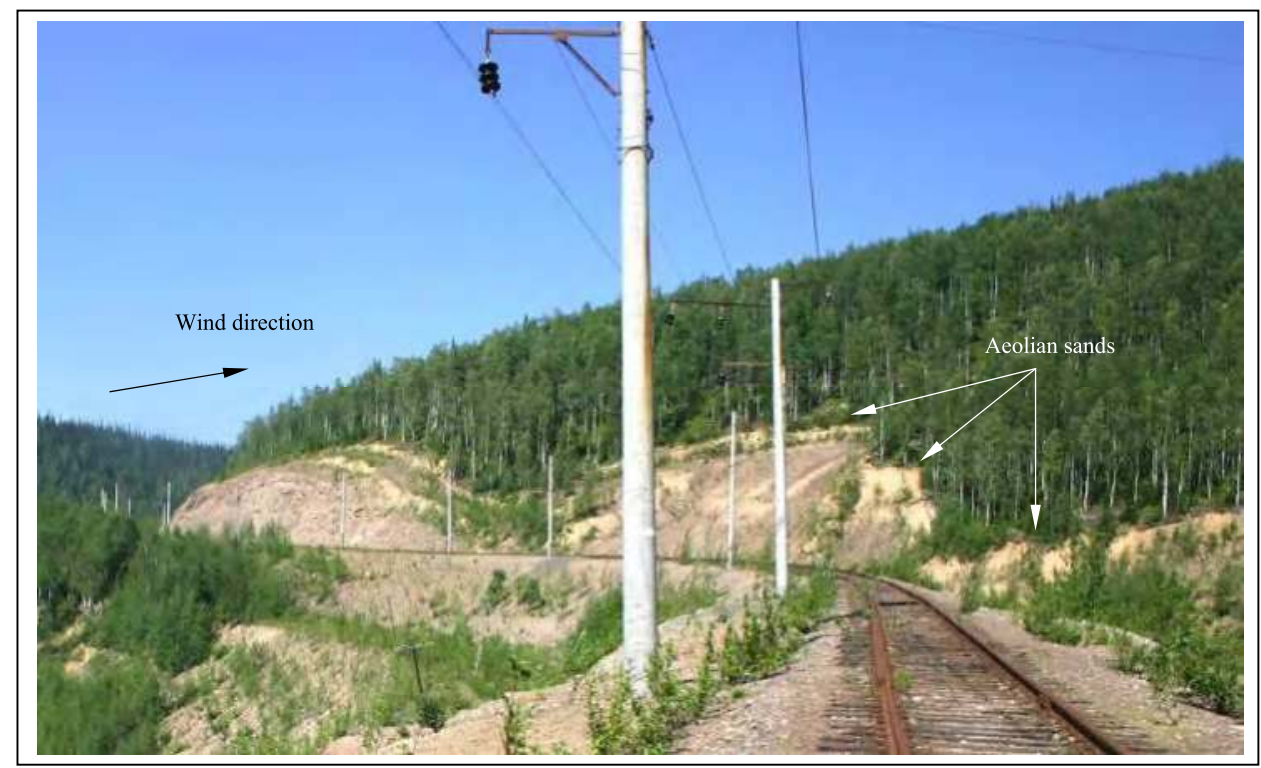

Fig. 18. Loessal whitish-yellow aeolian sands are well traceable in the form of a sand ribbon lying on hard rocks of the arms of the Baikalsky Range and clearly outline the mountain relief (Northwestern glaciations unit; Baikal-Amur Railroad; territory adjacent to the western entry into the Baikalsky tunnel $6.7 \mathrm{~km}$ in length.

\subsection{The matter composition of bottom sediments}

The matter composition of bottom sediments of Lake Baikal was studied by using cores from boreholes BDP-96 and BDP-98 which we collected with permission from the Baikal Drilling Project managers (Kuzmin et al., 2001). It should be noted at this point that the multichannel seismic research into bottom sediments in the middle part of Lake Baikal (in the area of boreholes BDP-96 and BDP-98) permitted T.G. Moore and collaborators (Moore et al., 1997) to divide them into two seismocomplexes. According to their data, the formation of Pleistocene-Holocene complex " $\mathrm{A}$ " is associated with the Angara development phase of Baikal, and its thickness is about 200 meters. The lithological investigations of core material from boreholes BDP-96-1; 2 and BDP-98 which exposed seismocomplex "A", showed that the matter composition of Pleistocene deposits is highly uniform (Kashik and Lomonosova, 2006; Kashik and Akulov, 2008). They are typical, horizontally occurring thin-layered polymictic graywackes that are represented by an alternation of aleurite clays and aleurite clay silts. Their mineralogical analysis intimated that light fraction consists of quartz, plagioclases, potassium feldspars, biotite, muscovite, chlorite, graphite, calcite, and vivianite as well as fragments of rocks, carbonificated plant tissues, remains of diatom loricae and spicules of sponges. Quartz content exceeds total percentage of feldspars, reaching $58 \%$. There occur both pure, colorless, transparent varieties and turbid, semitransparent grains. 
The amount of plagioclases varies from $11.6 \%$ to $34 \%$. The group of micas is represented by biotite, muscovite and chlorite. They are dominated by biotite whose amount varies from 0.4 to $39 \%$. Graphite and vivianite in the section of sediments reach $2.4 \%$. Vivianite is present both in the form of oxidized differences of grayish-blue color and in an unaltered form. The content of diatoms and loricae fluctuates over a wide range from trace amounts to $92 \%$; in this case, they produce interlayers of diatomites. Abrupt changes in concentration of diatom loricae are nearly coincident with intervals of increased contents of vivianite and sponge spicules. The yield of heavy fraction in analyte samples is very small, $17 \mathrm{~g} / \mathrm{kg}$. The highest contents of heavy minerals occur at the lower boundary of layer "A" (199 m). Hornblende is universally dominant (about $43 \%$ ), which has a prismatic angular-rounded shape of grains. Pyroxenes (up to $4 \%$ ) revealed the presence of the monoclinic as well as the rhombic differences. In the group of epidote, the main component is represented by epidote proper. Zoisite and clinozoisite are present in small amounts. The contents of the minerals from the group of epidote show a rather dramatic fluctuation, from total absence to $26 \%$, with the content averaging $10.5 \%$. Heavy fraction always includes ilmenite, magnetite, garnets, sphene, zircon, and apatite whose total content does not exceed $25 \%$. Sillimanite, kyanite, spinel, chromspinellids, anatase, staurolite, tourmaline, brookite, leucoxene, chloritoid, biotite, and chlorite occur in a few percent or some fractions of percent. An investigation into clay minerals in bottom sediments of Lake Baikal showed that their contents fluctuate from 16 to $52 \%$ of the sample volume. They are characterized by a low degree of perfection of structure, a high dispersion, and by the presence of mixed-layered hydromica-smectite and chlorite-smectite phases with variable contents of swelling packets. According to the degree of perfection of structure and dispersion, they are entirely identical to the varieties characteristic for even-aged deposits in the various hollows of the lake (Kashik et al., 2001).

\section{Discussion}

It is quite obvious that this overview of the research done is not exhaustive for the whole variety of glacial deposits in the Baikal mountainous region. This notwithstanding, we managed to relatively thoroughly reconstruct the activity of the Northwestern unit of Pleistocene glaciation. It encompassed the mountain structures of the northwestern part of the Baikal mountainous region and had a substantial influence on many other natural processes and phenomena at Lake Baikal.

\subsection{Glaciations and climatic records as deduced from bottom sediments of Baikal}

The Pleistocene climate was characterized by an alternation of the epochs of cold (glacial) and warm (interglacial) climate. A reconstruction of the palaeoclimate for the glacial ages is difficult because the deposits having origins at that time are not supported by palaeontological and spore-pollen evidence. The investigations of the glaciation areas which we and our predecessors have made indicate that mountain-valley glaciers were dominant during the Pleistocene. Furthermore, subsurface glaciation, or "permafrost", came to be of widespread occurrence. Thus, as early as V.A. Obruchev's epoch, mining of Bodaibo goldbearing alluvium buried under glacial deposits, by means of adits established that productive horizons are in the permafrost zone. According to data reported by V.A. Kudryavtsev (1978), the thickness of the permafrost zone within the region under 
investigation varies from 150 to $900 \mathrm{~m}$. The existence of permafrost zone provides a whole variety of advantages in commercial mining of placer gold. Firstly, permafrost protected the ancient gold-bearing alluvium against erosion due to the activity of glaciers. Secondly, since gold-bearing materials are frozen, they can be mined using adits, obviating the need to reinforce the walls. Thirdly, mining workings in permafrost are entirely devoid of water influx; therefore, they are relatively dry and do not require any forced water drain. In cases where the frozen alluvial complex is being mined through open-cast operations by means of hydraulic giants, the overlying fluvioglacial deposits are removed by means of a bulldozer. After that, the site thus prepared is thawing out for several months under the hot summer sun, so that hydraulic giants can easily flush out the thawed-out gold-bearing alluvium. In the mountains surrounding Baikal, products of activity from up to four glaciations are identifiable. On the other hand, it has not yet been possible to reveal any traces of glaciations older than the Sartanian glaciation in the lake's mountain surroundings because of their total scouring or redeposition. It should also be remembered that the manifestation of two or three glaciations would suffice to destroy the traces of all the previous ones. Hence it comes as no surprise that the records of bottom deposits from Baikal include traces of a significantly larger number of glaciations than revealed in the mountainous areas surrounding it. In documenting the deep-water drilling core, the composition of bottom sediments from the Pliocene revealed thin interlayers of glacial deposits that were produced by ice- and iceberg-rafting (Kuzmin et al., 2009). They are represented by fine glacial clays with the inclusion of sand and sparse gravel grains as well as coarse sand lenses. This suggests the existence of earlier glaciations than the Pleistocene glaciations. The presence of clays in deposits dating back to 2.5-2.6 mln years points to a sharp cooling in the Baikal mountainous region as early as the Late Pliocene. A significant cooling, with the age of 2.2 mln years, was recorded in buried soil horizons on Olkhon Island (Vorobyeva et al., 1995). On the other hand, according to data reported by E.B. Karabanov (1999), a record of biogenic silicon for the Brunhes epoch in the core for one of the boreholes contains 19 stadials (10 warm and 9 glacial). Comparison of the Baikal curve for biogenic silicon with the maritime isotopic curve permitted him to identify not only the correspondence of the number of peaks and minima but also their remarkable similarity. The degree of correlation of the Baikal records with maritime records is 0.71-0.84 (Peck et al., 1994; Colman et al., 1995). All this indicates that changes in the Pleistocene climate in Siberia were following the general planetary behavior of its development. In estimating the climate existing in the area of the lake over the course of the last glacial age, E.I. Ravsky (1972), and subsequently V.A. Belova (1985) pointed out that it was characterized y a decrease in annual mean temperatures by $8-12^{\circ} \mathrm{C}$, and by a considerable drying. Natural landscapes were dominated by cold glacial steppes. The mountain ranges surrounding the lake were covered by mountain-valley glaciers. All this led to a sharp decrease in production of the lake's phytoplankton, primarily the diatom phytoplankton. According to data reported by G.K. Khursevich (Kuzmin et al., 2009), the distribution of diatom algae in Pleistocene sediments of Baikal (about $1.6 \mathrm{mln}$ years ago) helped to identify 18 boundaries of extinction of diatom species. They attribute the cause for their extinction to the climatic minima of phases of a sharp climate cooling in the region. About 13.7 ths years ago, a warming set in, because the section of bottom sediments in Lake Baikal begins to incorporate valves of diatom algae forming a small peak on the interval of 13.7-11.3 ths years. This peak corresponds in terms of age to the warming of the final stage of the last glacial age. This warming has a complicated structure and includes two minima. A relative warming was followed by a 
cooling which is more pronounced in the opal record. The age of this cooling in the Baikal record is 11.3-9.5 ths years. A detailed analysis of the entire spore-pollen complex, obtained from the section of Baikal's bottom sediments, intimates two major restructuring boundaries of plant communities that occurred on land surface for the last $5 \mathrm{mln}$ years (Belova, 1985; Bezrukova et al., 1999). The first restructuring took place at the boundary of 2.8-2.5 mln years, and the second restructuring occurred at the boundary of $1.6 \mathrm{mln}$ years. The first boundary was distinguished by a considerable increase in steppe and forest-steppe plant communities, and by a significant reduction in forest communities. An abrupt change of this kind is indicative of a sharp cooling and drying of the climate over the range of 2.8-2.5 mln. Years, which is supported by data on the first glaciation of Asia during that time span. After that cooling, the plant communities did not restore their structure in full measure, and larch, Siberian stone pine, spruce, and fir acquired a predominant significance, whereas the representatives of the moderately thermophilic flora remained in the form of a rare inclusion. Vegetation of the forest-tundra type shaped itself during the second cooling. A restructuring at the boundary of $1.6 \mathrm{mln}$ years led to an almost total disappearance of moderately thermophilic species of the dendroflora, and to the formation of the type of vegetation similar to the contemporary one (cold-enduring boreal-taiga vegetation). It should be emphasized that the previously obtained results from lithologo-facial and other analyses for the boreholes under the Baikal Drilling Project (Team ..., 2004) permitted the project participants to project about 30 climatic minima. It is beyond reason to say whether they were glaciations or short-lasting cooling phases because of lack of adequate supporting evidence. The surprisingly large number of Pleistocene glaciations in Siberia or in Central Asia was beyond the imagination. Hence, not all of the reconstructed climatic minima must be viewed as a glaciation; instead, they should be interpreted as local climatic fluctuations within the Baikal hollow. A particular climatic minimum can only be associated with glaciation, if it has been ascertained that the deposits that had formed under the conditions of the interglacial climate preceding and following the glaciation will be detected in river and lake terraces of the study region. In any case, interpretation of the results of palaeoclimatic records for Baikal's bottom sediment core demands further elaboration.

\subsection{Number of glaciations and their datings}

The question as to the number of glaciations in the Baikal mountainous region was posed for the first time by P.A. Kropotkin (1876) and has remained open till the present. Perhaps, the answer to this question is simple. It implies that the glacial deposits were studied in different areas that were retreating during degradation of blanket glaciations and mountainvalley glaciations. In the areas at the largest distance from the center of glaciation, the remaining complexes of terminal morainic deposits provide evidence in support of the manifestation of a whole variety of glaciations. On the other hand, in areas which are at the shortest distance from its center, the remaining products of activity of the glaciers correspond with a smaller number of glaciations. This is complicated further by the fact that, orographically, the middle part of the Siberian Platform from which the glaciation was advancing toward Lake Baikal constitutes the Middle-Siberian Upland. It consists of a large number of leveled (by the Quaternary glaciation) plateaus with lake-bog landscape and poor exposure. In all likelihood, from the Pliocene to the Holocene the upland was under a thick blanket glaciation which was descending southward to the present-day location of the Lower-Tunguska River. According to data reported by T.A. Burashnikova and collaborators (Burashnikova et al., 1978), the Arctic glacier mantle of the last glaciation that, in East 
Siberia, almost reached the mouth of the Lower-Tunguska River, was 1-2 km in thickness. At the same time, as pointed out above, the glaciations within the Baikal mountainous region had a mountain-valley pattern. It is important to note that the Arctic blanket glaciation was separated from deposits that had been formed by the largest terminal moraine descending the Baikal mountains, by the off-glacier zone about a thousand kilometers in width. Its length was about two thousand kilometers (from the Vekhoyansk mountains on the east to the Yenisei mountain-ridge and Eastern Sayan on the west). A buried soil of the steppe type was discovered on huge expanses of the off-glacial zone which we call the Angara-Tunguska zone (Ravsky et al., 1964). The Angara-Tunguska off-glacial zone was an immense pasture land with succulent grass irrigated by thawing glaciers providing habitat to mammoths, woolly rhinoceros, and other mammals, including primitive man. This zone was the home to the numerous camp sites of ancient man in East Siberia, including in the city of Irkutsk. The morainic deposits which we investigated on the Minya-Okunaika interfluve were termed the Kunermian glaciation by A.A. Kul'chitsky (1973). The Kunermian glaciation was the oldest among the visually recorded glaciations. It was one of the most severe glaciations in East Siberia, time-coincident with the Samarian glaciation of West Siberia, as well as to the Riss-I glaciation, according to the Alpine Stratigraphic Chart, and is dated back to the end of the first half of the Mid-Pleistocene $\left(\mathrm{Q}_{\mathrm{II}}{ }^{2}\right)$. In Europe, the Riss glaciation started about 250 ths years ago. According to data reported by V.M. Gavshin, S.A. Arkhipov, V.A. Bobrov and collaborators (Gavshin et al., 1998), by analyzing the distribution of natural radioactive elements in Holocene-Pleistocene deep-water deposits of Lake Baikal, they were able to assign the time of the Samarian glaciation to the boundary of 276-247 ths years, and the subsequent Shirtian Interglacial, to the interval of 247-190 ths years. According to their data, the Tazovian glaciation manifested itself 190-127 ths years ago, the Kazantsevian Interglacial - 127-73 ths years ago, and the Yermakovskoye and Sartanian glaciations, respectively, 73-38 ths years ago and 28-11 ths years ago. The last two glaciations are separated by the Kargian Interglacial (38-28 ths years ago). Thus the first wave of Pleistocene glaciation was responsible fro the fact that the Kunerma glaciers caused a maximum possible advance of the morainic deposits which, subsequently, experienced multiply occurring intense erosion processes thereby leading to their significant dwindling. With the distance from the main front of the moraines, the amount of coarse-debris material decreases and its roundedness increases. The second wave of substantial cooling corresponds to the Tazovian glaciation of West Siberia as well as to the Riss-II glaciation according to the Alpine Stratigraphic Chart, and dates back to the end of the Mid-Pleistocene $\left(\mathrm{Q}_{\mathrm{II}}{ }^{4}\right)$. Morainic deposits of this phase of glaciation were discovered on the Minya-Okunaika watershed and in the area of urochishche Toka-Makit. The Kazantsevian warming was followed by one of the strongest glaciations, Yermakovian $\left(\mathrm{Q}_{\text {III }}^{2}\right)$, which was time-coincident with the Würm-I glaciation (Alpine Stratigraphic Chart). Products of the activity of this glaciation were revealed on the Minya-Okunaika watershed. It was time-coincident with the formation of terrace complexes of the Ulkan (river mouth, 810-meter terrace), the Kirenga (10-12-meter terrace), and the Munok (8-10-meter terrace). The Kargian Interglacial set in, which was replaced by the fourth phase of glaciation, the Sartanian, at the end of the Late-Pleistocene $\left(\mathrm{Q}_{\mathrm{III}}^{4}\right)$ and, according to the Alpine Stratigraphic Chart, in time coincidence with the Late Würm (Würm-III). Thus the Late Pleistocene sedimentary complex is comprised of deposits of two interglacial and two glacial horizons. The first interglacial horizon is represented by lacustrine sands in the straths of the low Baikalian terraces, overlain in places by morainic debris deposits. The glacial horizons as 
such were opened in the composition of four Baikalian terraces which are composed of morainic and fluvioglacial deposits. For the more detailed solution of the problem regarding the number of glaciations at Baikal, in addition to invoking conventional techniques and the aforementioned methods, some researchers used absolute geochronology data (thermoluminescence and radiocarbon). As yet, thee number of resulting datings is small; nevertheless, the currently available C14 and TYa-dates provided some insight into the solution of a number of questions. More specifically, in the most complete section of Pleistocene deposits in the northwestern part of Baikal, in the valley of the Rel River, on the semi-scoured moraine of maximum advance there occur Rel deluvial-proluvial interglacial sands with Coelodonta antiquitatus with C14 - $25880 \pm 350$ SOAN-829, which correlated with (occurring in this same area) palaeosoils of the Kurlinskaya camp site, C14 - $24060 \pm$ 570 SOAN-1397 (Mats et al., 2001). Based on this, it was possible to infer the lower boundary (the beginning) of Late-Pleistocene glaciation. The above-lying sand-pebble deposits of the first Baikalian terrace formed during the first optimum of the Holocene, with deposits of wave-cut grottoes being level with the terrace, with a dating C14 -7890 \pm 235 SOAN-580. It important to notice that the above-lying deposits contain strata with Neolitic culture (C14 $4470 \pm 65$ SOAN-830). The research done by E.E. Kononov (2009) ascertained that the formation of the glacial barrier-lacustrine basin in the Muisko-Kuandinskaya hollow (the northern part of Baikal) occurred about 40 еры years ago. The entire complex of sandy deposits occurring in this basin is combined into the composition of the Kobylinskaya formation. The base of the formation was dated from stump wood: $38320 \pm 775,40500 \pm 930$, and $36500 \pm 2500$ (KI-3951) (Kul'chitsky, 1995). The upper boundary of the formation was established at borehole 14a drilled on the left-bank terrace of the Mudirikan River. A dating of 22300 years was obtained from peaty layers at a depth of $95 \mathrm{~km}$ (SOAN-2484) (Filippov, 1997). The formation start of lacustrine deposits is time-coincident with burial of tree trunks, and its cessation coincides with the termination of lacustrine sedimentation as a result of the discharge of the barrier palaeolake at the interglacial period. Thus the lifetime of the barrier lake fits in the interval ranging from 38 to 22 thousand years and corresponds to the Karginian Interglacial. Nowadays it is generally recognized that the Baikal hollow includes deposits corresponding to the Karginian interglacial, or Megainterstadial. The Karginian warming in Siberia was documented sufficiently clearly by many investigators (Rayevsky, 1972; Belova, 1985; Vorobyeva, 1994).

\subsection{Embodiment of Pleistocene glaciations in the deposits of river floodplains and terraces}

According to present views, the valleys of the Lena, Angara, Lower Tunguska and Vilyui rivers had formed as early as the end of the Pliocene. The Late Pleistocene glaciation encompassed largely their upper portions which have retained a more-or-less clearly pronounced shape of troughs till the present. The smoothed shape of the benches and buttresses on the valley slopes is well preserved on the outcrops of hard rocks. Gentle platforms of the smoothed benches often are the home to erratic boulders and exotic pebble gravel witnessing the former filling of the valleys with the ice. Degradation of glaciation is represented mainly by various accumulative formations having a paragenetic connection with it. The ground moraine is composed of debris material mostly not larger than pebble in size. Only rarely does it include small boulders. Even though the ground moraine is a 
uniform mechanical mixture without any obvious glacio-dynamical textures, it drastically differs precisely in this feature from the ablation moraine saturated with boulders and blocks. Such a difference in the lithology of the ground and ablation moraines is also conserved when terrace complexes form on them. Morainic material that is present in the deposits of the river terraces is readily identified and diagnosed. Beyond the edge of the Late-Pleistocene moraines, traces of glacial activity are observed in the eastern and northern halves of the Lake Baikal hollow along the valleys of the Lena, Vitim and Patoma rivers, but such attributes are lost in places where the rivers enter planate areas. This notwithstanding, indirect signs of, at least, Sartanian glaciation can be found even in floodplain deposits of the off-glacial zone. They are represented by typical varieties of cryogenic formations in the form of frost wedges and fissures, cryoturbations, sinkholes, etc. (Fig. 19). Nevertheless, given the present stage of understanding the friable deposits in the mouth area of the Angara River, one cannot draw any definite conclusions regarding the glacial processes in this area. The high terraces are weakly exposed; therefore, the composition and structure of the deposits composing them have to be inferred from rather disconnected outcrops. Our survey of these terraces suggests that 1) the high terraces are composed of sediments of a common, complex-structured layer which is characterized by clearly pronounced facial changes both in section and in strike; 2) from the base of the layer forming part of the high terraces, upward the section there is a decrease in cementation density of the deposits; 3 ) the deposits of the high terraces contain varying amounts of large erratic boulders and blocks concentrated largely at the upper termination of the terrace; 4) the high terraces are largely composed of stratified, poorly rounded, small-size, free-flowing pebbles, gravel and debris

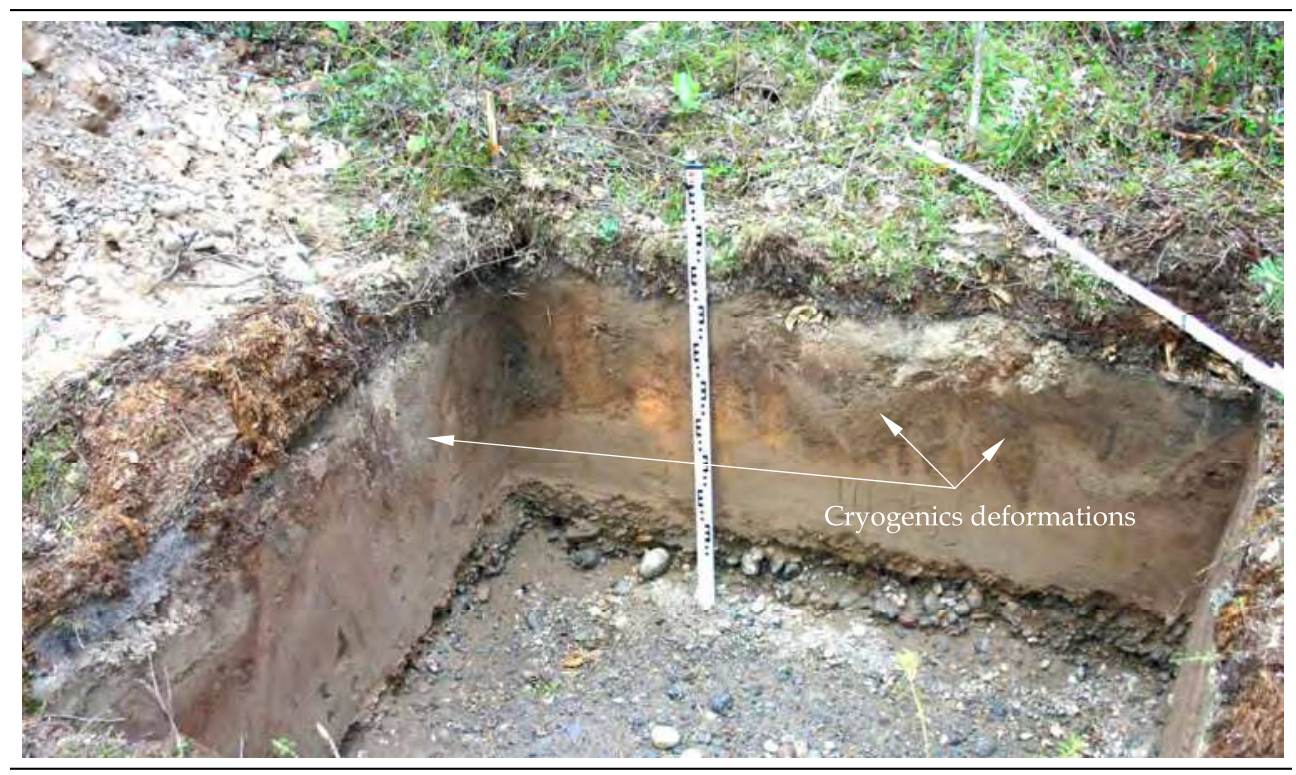

Fig. 19. Cryogenics deformations in floodplain deposits of the Angara-Tunguska off-glacial zone (Northwestern glaciations unit; left bank of the Kirenga River in the vicinity of the settlement of Magistralny, pit No. 5). 
which do almost not contain any clay material; in some places, however, they include large erratic boulders and blocks, and 5) pebbles of the low terraces are fluvioglacial and contain a relatively large amount of clay material. In closing this Section, it is worth noting that the loessal aeolian sands that were opened on the arms of the Baikal mountains (see Fig. 18) constitute a reflection of the powerful Aeolian processes occurring widely after the Glacial Age. The huge exposed planate area of the Prebaikalian trough following the thawing out of the ice and snow was covered with morainic, aqueous-glacial, fluvioglacial-debris flow and other derivative glacial deposits and immediately became the scene of Aeolian activity. Northwesterly storm winds were producing huge amounts of dust, transporting it to considerable distances. As the wind was losing energy, aleuro-pelitic material was uniformly deposited on the surfaces of the mountains, and on the mountain slopes.

\section{Conclusions}

The research reported here suggests the following conclusions: 1) the morainic complex of the Baikal region is composed by sandy-boulder-block and block-boulder-sandy unstratified deposits, with the occasional inclusion of scree and gravel, the main filling material in which comprises arkose sands with magnetite-amphibole assemblage of heavy fraction; 2) fluvioglacial deposits are of the most widespread occurrence among all the types of glacial formations, and 3) the aqueous-glacial layers are overlain by loamy sands and loams which often contain scree and buried soils and are culture-host ones. Their composition revealed all archaeological finds; 4) during the Pleistocene, blanket glaciation that had been advancing from the Arctic Ocean did not reach Lake Baikal and stopped about one thousand kilometers from it. It was separated from the glacial formations of the Baikal mountainous region by a vast Angara-Tunguska off-glacial zone with steppe landscape; 5) the problem of a correlation of the climatic minima as identified in the bottom sediment core from Lake Baikal, with classical glaciations of Europe involves a difficulty in detecting timecoincident continental glacial deposits in the arms of the mountains or in their valleys, and in the terraces of rivers or lakes; 6) during the Pleistocene, at Lake Baikal there occurred four mountain-valley glaciations: Kunermian (Samarian; Riss-I; 276-247 ths years ago), Tazovskian (Riss-II; 190-127 ths years ago), Yermakovian (Zyryanian, Würm-I; 73-38 ths years ago), and Sartanian (Würm-III; 28-11 ths years ago), and 7) the distinctive characteristics of the glaciations of the Baikal mountainous region were a dramatic aridization of the climate, and a widespread occurrence of aeolian processes.

\section{References}

Adamenko, O.M.; Kul'chitskii, A.A. \& Adamenko, R.S. (1974). The Stratigraphy of the Quaternary Deposits in the Cisbaikalian Basin, Geologiya i Geofizika (Soviet Geology and Geophysics), Vol.15, No.8, pp. 34-42, ISSN 0016-7886

Akulov, N.I., Agafonov, B.P. \& Krasnoshchekov, V.V. (2008). Aeolian Deposits Covering Camp Sites of Ancient Man, Litologiya i poleznye iskopaemye, No.2, pp. 209-222, ISSN 0002-3337

Akulov, N.I. \& Rubtsova, M.N. (2011). Aeolian Deposits of Rift Zones, Quaternary International, No.234, pp. 190-201, ISSN 1040-6182 
Akulov, N.I., Agafonov B.P. \& Rubtsova M.N. (2008). Glacial Deposits and "Watershed Pebbles" in Western Baikal Area, Russian Geology and Geophysics, Vol.49, No.1, pp. 28-39, ISSN 0016-7886

Akulov, N.I. (2004). Paleogeography and Conditions of Accumulation of Devonian Sediments in the Southern Siberian Platform, Stratigrafiya. Geologicheskaya Korrelyatsiya, Vol.12, No.3, pp. 26-36, ISSN 0869-592X

Back, S. \& Strecker, R.M. (1998). Asymmetric Late Pleistocene Glaciations in the North Basin, of the Baikal Rift, Russia, J. of the Geological Society, Vol.155, pp.61-69, ISSN 00167649

Bazarov, D.B. (1986). The Cainozoic of the Prebaikalia and Western Transbaikalia, Nauka, Novosibirsk, Russia

Bezrukova, E.V., Kulugina, N.V., Letunova, P.P. \& Shestakova, O.N. (1999). The Directedness of Vegetation and Climate Changes in the Baikal Region for the Last 5 Million Years (as Deduced From data of Palynological Investigations of Lake Baikal), Geologiya i geofizika, Vol.40, No.5, pp. 739-749, ISSN 0016-7886

Belova, V.A. (1985). Vegetation and Climate of the Late Cainozoic in the South of East Siberia, Nauka, Novosibirsk, Russia

Burashnikova, T.A., Grosvald, M.G. \& Suyetova, I.A. (1978). The Volume of Arctic Glacial Cover at the Epoch of the Last Glaciation of the Earth, DAN SSSR, Vol.238, No.5, pp. 1169-1172, ISSN 0869-5652

Chersky, I.D. (1877). Opinions Regarding the Former (in the Post-Glacial Period) Highly Significant Occurrence of Waters of the Arctic Ocean in Siberia, Izvestiya Sibirskogo otdeleniya Russkogo geograficheskogo obshchestva, Vol.III, pp. 86-113.

Colman, S.M., Peck, J.A., Karabanov, E.B., Carter, S. J., Bradbury, J. P., King, J.W. \& Williams, D.F. (1995). Continental Climate Response to Orbital Forcing From Biogenic Silica records in Lake Baikal, Nature, Vol.378, (30 November 1995) pp. 769771, ISSN 0028-0836

Dumitrashko, N.V. (1952). Geomorphology and Palaeogeography of the Baikal Mountainous Region, In: Materials on Geomorphology and Palaeogeography of the USSR (ed. by V.A. Obruchev), Izd-vo AN SSSR, Moscow,191 p.

Filippov, A.G. (1997). Detailing of the Local Litho- and Biostratigraphic Differentiation of Quaternary Deposits on the Basis of Studying Reference Sections for Improving StratigraphicPatterns of the Muiskaya Series and the Angara-Lena Block of the South of E.Siberia, Irkutsk, Russia

Florensov, N.A. (1960). Mesozoic and Cenozoic Depressions in the Baikal Area, Izd. AN SSSR, Moscow.

Grossvald, M.G. (1965). Development of Topography of the Sayan-Tuva Upland, Nauka, Moscow.

Grossvald, M.G. (2002). P.A. Kropotkin and the Problem of Ancient Glaciation of Siberia, In: P.A. Kropotkin's Ideas and Natural Science. On P.A. Kropotkin's Biography, Moscow, pp. 17-36.

Gurulev, A. (1959). On the Age of the Quaternary Glaciation in the Northern Baikal Region, Trudy VSGI, seriya geologicheskaya, Issue 2, Materials on Geology of East Siberia, Irkutsk, pp. 175-186.

Imbrie, J. \& Imbrie, K.P. (1979). Ice Ages Solving the Mystery, New Jersey, Hillside. 
Imetkhenov, A.B. (1987). Late Cainozoic Deposits in the Shore Area of Lake Baikal, Novosibirsk: Nauka, Russia

Karabanov, E.B., Prokopenko, A.A., Williams, D.F. \& Colman, S.M. (1998). The Link Between Insolation, North Atlantic Circulation and Intense Glaciations in Siberia During Interglacial Periods of Late Pleistocene, Quaternary Research, Vol.50, pp. 4655, ISSN 0033-5894

Karabanov, E.B. (1999). Geological Structure of Sedimentary Layer of Lake Baikal and Reconstruction of Climate Change of Central Asia in the Late Cainozoic, In: Abstract of Doctor of Geologic-Mineralogical Sciences Degree Dissertation, Institute of Lithosphere RAS, Moscow.

Karabanov, E. B., Prokopenko, A. A., Williams, D. F. \& Khursevich, G. K. (2000). Evidence for Mid-Eemian Cooling in Continental Climatic Record From Lake Baikal, Journal of Paleolimnology, Vol.23, pp. 365-371, ISSN 0921-2728

Kashik, S.A. \& Akulov, N.I. (2008). Pleistocene-Miocenic Sedimentation in Baikal Lake. The $7^{\text {th }}$ International Symposium on Environmental Changes in East Eurasia and Adjacent Areas - High Resolution Records of Terrestrial Sediments, pp. 83-85, UlaanbaatarHatgal, Mongolia, August-September, 28-3, 2008

Kashik, S.A., Lomonosova, T.K. \& Fileva, T.S. (2001). Genetic Types of Clay Minerals in Bottom Sediments of the Southern Depression of Lake Baikal, Geologiya i geofizika, Vol.42, Nos.1-2, pp. 164-174, ISSN 0016-7886

Kashik, S.A. \& Lomonosova, T.K. (2006). Cainozoic Sediments of the Underwater Akademichesky Range in Lake Baikal, Litologiya i poleznyye iskopayemye, No.4, pp. 339-353, ISSN 0002-3337

Kazakevich, Yu.P. \& Vashko, N.A. (1965). Role of Glacial Processes in the Preservation and Destruction of Gold-Bearing Placers as Exemplified by Some Areas of Siberia, In: Geology of Placers, Nauka, Moscow, pp. 157-164.

Kul'chitsky, A.A. (1973). Deposits and Paleontology of the Epoch of the Maximum Glaciation in the Cisbaikalian Basin, Geologiya i geofizika, No.9, pp. 60-66, ISSN 00167886

Kul'chitsky, A.A. (1985). Pleistocene Glaciations of the Mountains of the Northwestern Baikal Region in the BAM Zone (Exemplified by the Kunerma River Basin), Geologiya i geofizika, No. 2, pp. 3-9, ISSN 0016-7886

Kul'chitsky, A.A. (1993). Deposits and Palaeogeography of the Epoch of the Maximum Glaciation of the Baikal Region, Geologiya i geofizika, No.9, pp. 60-67, ISSN 0016-7886

Kul'chitsky, A.A. (1995). Deformation of Cainozoic Deposits in the Muisko-Kuandinskaya Depression of the Baikal Rift Zone, In: RFBR in the Siberian Region, Irkutsk, pp. 3536.

Kononov, E.E. (2009). On the Origin of Sandy layers in the Northern Baikal Region, Vestnik IrGTU, No.4(40), pp. 23-27, ISSN 1814-3520

Krivonogov, S.K. (2010). Sedimentation in the Hollows of the Baikal Rift Zone in the Late Pleistocene and Holocene. Author's Abstract of Doctor of Geological-Mineralogical Sciences Dissertation, Izd-vo IGM SO RAN, Novosibirsk, Russia

Kropotkin, P.A. (1876). Studies on the Glacial Period, St. Petersburg, Russia

Kudryavtseva, V.A. (1978). General Permafrost Science, Moscow: Izd-vo MGU, Russia

Kuzmin, M.I., Karabanov, E.V., Kawai, T., Williams, D., Bychinsky, V.A., Kerber, E.V., Kravchinsky, V.A., Bezrukova, E.V., Prokopenko, A.A., Gelety, V.F., Kalmychkov, 
G.V., Goreglyad, A.V., Antipin, V.S., Khomutova, M.Yu., Soshina, N.M., Ivanov, E.V., Khursevich, G.K., Tkachenko, L.L., Solotchina, E.P., Yoshida, N. \& Gvozdkov, A.N. (2001). Deep Drilling on Baikal - Main Results, Geologiya i geofizika, Vol.42, Nos.1-2, pp. 8-34, ISSN 0016-7886

Kuzmin, M.I., Khursevich, G.K., Prokopenko, A.A., Fedenya, S.A. \& Karabanov, E.B. (2009). Centric Diatoms in Lake Baikal During the Late Cenonzoic: Morphology, Systematics, Stratigraphy and Stages of Development (Based on the Deep Cores of the Baikal Drilling Project), Editor-in-Chief Professor A.M. Spiridonov, Academic Publishing House "GEO", Novosibirsk, ISBN 978-5-9747-0137-5

Ladokhin, N.P. (1959). Toward the Ancient Glaciation of the Baikal Region, In: Materials on the Geology of East Siberia. Seriya geologicheskaya, Issue 2, Irkutsk, pp. 153-173.

Lamakin, V.V. (1961). The Quaternary Geology of the Baikal Hollow and of Its Surrounding Mountains, In: Some Questions of the Geology of the Anthropogene (to the $4^{\text {th }}$ Congress of the INQUA to Be Held in Warsaw in 1961), Moscow: Izd-vo AN SSSR, pp. 152-165.

Lamakin, V.V. (1963). Glacial Deposits in the Littoral Strip of Baikal, Trudy komissii po izucheniyu chetvertichnogo perioda AN SSSR, issue 21, pp. 126-147.

Logachev, N.A., Antoshchenko-Olenev, I.V., Bazarov, D.B. \& Galkin, V.I. (1974). The Uplands of the Prebaikalia and Transbaikalia, Nauka, Moscow, Russia

Mats, V.D., Ufimtsev, G.F. \& Mandelbaum, M.M. (2001). The Cainozoic of the Baikal Rift Hollow: Structure and Geological History, Novosibirsk: Izd-vo "Geo", Russia

Mats, V.D., Pokatilov, A.G., Popova, S.M., Kravchinsky, A.Ya., Kulagina, N.V. \& Shimarayeva, M.K. (1982). The Pliocene and Pleistocene of Middle Baikal, Novosibirsk: Nauka, Russia

Moore, T.G., Klitgord, K.D., Golmstok, A.Ya. \& Weber, E. (1997). The Central and North Basins of Lake Baikal:The Early Phase of Basin Formation, Geol. Soc. Amer. Bull., Vol.9, No.6, pp. 746-766, ISSN 0016-7606

Obruchev, V.A. (1918). P.A. Kropotkin (On the 75th Anniversary of His Birth), Priroda, Nos.46, pp. 309-322.

Obruchev, V.A. (1931). Attributes of the Glacial Period in Northern and Central Asia, Byulleten Komissii po izucheniyu chetvertichnogo perioda AN SSSR, No.3, pp. 43-120.

Olyunin, V.N. (1969). Ancient Glaciation of Khamar-Daban, In: Geography and Geomorphology of Asia, Nauka, Moscow.

Osadchy, S.S. (1982). On the problem of the Relationship Between pluvial and Glacial Epochs on the Territory of the Transbaikalian North, In: The Late Cainozoic History of Lakes in the USSR, Nauka, Novosibirsk, pp. 61-71.

Peck, J., King., Colman, S.M. \& Kravchinsky, V.A. (1994). A Rock-Magnetic Record From Lake Baikal, Siberia: Evidence for the Late Quaternary Climate Change, Earth Planet Sci. Lett., Vol.122, pp. 221-238, ISSN 0012-821X

Ravsky, E.I., Alexandrova, L.P., Vangengeim, E.A., Gerbova, V.G. \& Golubeva, L.V. (1964). Anthropogenic Deposits in the South of East Siberia, Nauka, Moscow.

Ravsky, E.I. (1972). Sedimentation and Climates of Inner Asia in the Anthropogene, Nauka, Moscow, Russia

Rukhin, L.B. (1969). The Foundations of Lithology, Nedra, Leningrad, Russia

Sheinkman, V.S. (2002a). Testing the S-S Technology of Thermoluminiscence Dating on the Sections Along the Shores of the Dead Sea, Its Implementation in Mountainous 
Altai, and Palaeo Geographical Interpretation of Results, Arkheologiya, etnografiya $i$ antropologiya of Eurasia, Vol.2, No.10, pp. 22-37, ISSN 1563-0102

Sheinkman, V.S. (2002b). Age Diagnostics of Glacial Deposits in Mountainous Altai and Their Testing Against the Sections of the Dead Sea, Materialy glatseologicheskikh issledovanniy, Vol.93, pp. 41-55, ISSN 0130-3686

Sheinkman, V.S. \& Antipov, A.N. (2007). Baikal's Palaeoclimatic Records: Disputable Issues Relating to Its Possible Correlation With Ancient Glaciations of Siberia's Mountains, Geografiya i prirodnye resursy, No.1, pp. 6-13, ISSN 0206-1619

Shutov, V.D. (1972). Classification of Sandstones, In: Graywackes, Moscow: Nauka, pp. 21-24.

Strakhov, N.M. (Ed.) (1957). Methods of Studying Sedimentary Rocks, Moscow: Gosgeoltekhizdat.

Team of "Baikal-Drilling" Project Participants. Continuous Record of Climatic Changes in Sediments of Lake Baikal for the Last 5 Million years. (1998). Geologiya i geofizika, Vol.39, No.2, pp. 139-156, ISSN 0016-7886

Team of Project Participants. High-Resolution Sedimentary record from the New Core BDP99 Deep-Water Drilling on the Posolskaya Bank in Lake Baikal. (2004). Geologiya $i$ geofizika, Vol.45, No.2, pp. 163-193, ISSN 0016-7886

Tsetlin, S.M. (1964). Comparison of Quaternary Deposits and Off-Glacial Zones of Central Siberia (Lower-Tunguska Basin), Nauka, Moscow.

Velichko, A.A. (1957). Kropotkin as the Originator of the Theory of the Glacial Period, Izvestiya AN SSSR, seriya geograficheskaya, No.1, pp. 122-126.

Vorobyeva, G.A. (1994). Palaeoclimates Around Baikal in the Plestocene and Holocene. In: Baikal as a Natural Laboratory for the Study of Global Changes, Izd-vo Lisna, Irkutsk, Vol. 2, pp. 54-55.

Vorobyeva, G.A., Mats, V.D. \& Shimarayeva, M.K. (1995). Palaeoclimates of the Late Cainozoic of the Baikal Region, Geologiya i geofizika,Vol.36, No.8, pp. 82-96, ISSN 0016-7886

Voskreswensky, S.S. (1959). Geomorphology of Siberia, Izd-vo MGU, Moscow, Russia

Voyeikov, A.I. (1881/1952). Climatic Conditions of Glacial Phenomena in the Past and at Present, In: Selected Works, Izd-vo AN SSSR, Moscow, Vol.III, pp. 321-364.

Yatsenko, A.A. (1950). On the Glaciation of the Baikal Mountainous Region, Voprosy geografii i geomorpfologii, IGO, Moscow, pp. 179-188.

Zamoruyev, V.V. (1971). On the Character and Age of Quaternary Glaciation of the Mountains in the Southern Transbaikalia and Prebaikalia, In: Chronology of the Glacial Age, Izd-vo GO SSSR, Leningrad, pp. 92-100.

Zamoruyev, V.V. (1978). The Stadial Character of Glacial Retreat and the Position of the Snowline in the Khamar-Daban Range During the Late Quaternary Glaciation, Izvestiya VGO, Vol.II0, pp. 526-530, ISSN 0869-6071

Zamaraev, S.M., Adamenko, O.M., Ryazanov, G.V., Kul'chitsky, A.A., Adamenko, R.S. \& Vikent'eva, N.M. (1976). Structure and History of Evolution of the Cisbaikalian Piedmont Depression, Nauka, Moscow, Russia

Zolotarev, V.G. (1961). Geomorphology and Geology of Quaternary Deposits in the Northern Part of the North-Baikal Upland, In: Materials on Geology and Mineral Resources of Irkutsk Oblast, Issue 1, No. 28), pp. 40-61. 


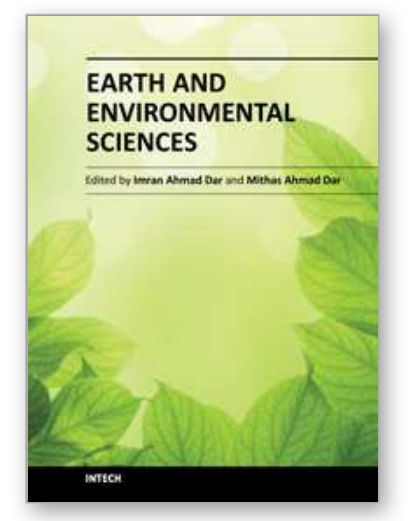

\author{
Earth and Environmental Sciences \\ Edited by Dr. Imran Ahmad Dar
}

ISBN 978-953-307-468-9

Hard cover, 630 pages

Publisher InTech

Published online 07, December, 2011

Published in print edition December, 2011

We are increasingly faced with environmental problems and required to make important decisions. In many cases an understanding of one or more geologic processes is essential to finding the appropriate solution. Earth and Environmental Sciences are by their very nature a dynamic field in which new issues continue to arise and old ones often evolve. The principal aim of this book is to present the reader with a broad overview of Earth and Environmental Sciences. Hopefully, this recent research will provide the reader with a useful foundation for discussing and evaluating specific environmental issues, as well as for developing ideas for problem solving. The book has been divided into nine sections; Geology, Geochemistry, Seismology, Hydrology, Hydrogeology, Mineralogy, Soil, Remote Sensing and Environmental Sciences.

\title{
How to reference
}

In order to correctly reference this scholarly work, feel free to copy and paste the following:

N.I. Akulov and M.N. Rubtsova (2011). Deposits from the Glacial Age at Lake Baikal, Earth and Environmental Sciences, Dr. Imran Ahmad Dar (Ed.), ISBN: 978-953-307-468-9, InTech, Available from: http://www.intechopen.com/books/earth-and-environmental-sciences/deposits-from-the-glacial-age-at-lakebaikal

\section{INTECH}

open science | open minds

\section{InTech Europe}

University Campus STeP Ri Slavka Krautzeka 83/A 51000 Rijeka, Croatia Phone: +385 (51) 770447 Fax: +385 (51) 686166 www.intechopen.com

\author{
InTech China \\ Unit 405, Office Block, Hotel Equatorial Shanghai \\ No.65, Yan An Road (West), Shanghai, 200040, China \\ 中国上海市延安西路65号上海国际贵都大饭店办公楼 405 单元 \\ Phone: +86-21-62489820 \\ Fax: $+86-21-62489821$
}


(C) 2011 The Author(s). Licensee IntechOpen. This is an open access article distributed under the terms of the Creative Commons Attribution 3.0 License, which permits unrestricted use, distribution, and reproduction in any medium, provided the original work is properly cited. 